\title{
ESTUDIO DE LA EVOLUCIÓN JURISPRUDENCIAL DEL DELITO DE ENALTECIMIENTO DEL TERRORISMO. ESPECIAL REFERENCIA A AQUELLOS CASOS QUE HAN ADQUIRIDO MAYOR REPERCUSIÓN MEDIÁTICA ${ }^{1}$
}

\author{
Lucas G. Menéndez Conca \\ Investigador predoctoral del Grupo de Estudios Penales ${ }^{2}$ \\ Universidad de Zaragoza
}

\begin{abstract}
Sumario: I. Introducción. II. Evolución jurisprudencial del art. 578 CP. 1. Interpretación estrictamente literal. 2. Criterio interpretativo del Tribunal Constitucional. 3. Relevancia del contexto y de la finalidad del autor. 4. Contrapuesta valoración del riesgo: conflicto con el derecho de creación artística. 5. La atenuación de las penas en aplicación del art. 579 bis.4 CP. III. Conclusiones. IV. Bibliografía.
\end{abstract}

Resumen: El delito de enaltecimiento del terrorismo se introdujo en el art. $578 \mathrm{CP}$ en el año 2000, pero ha sido a partir del año 2015 cuando ha comenzado a producirse una proliferación de sentencias dictadas por su comisión, algunas de las cuales han tenido una gran repercusión mediática. Ello ha dado lugar a que se haya generado una interesante evolución jurisprudencial en esta materia, la cual ha provocado cambios sustanciales en la naturaleza jurídica de este delito. En este trabajo se

1 Texto a partir de la ponencia titulada «Delitos de enaltecimiento del terrorismo a través de música y canciones», presentada en el Seminario de debate sobre libertad de expresión y Derecho Penal: «Los límites de la libertad de expresión en el Derecho Penal: los delitos de opinión», organizado por el Grupo de Estudios Penales y celebrado en la Facultad de Derecho de la Universidad de Zaragoza el 19 de febrero de 2019.

2 Este trabajo se inserta dentro de las líneas de investigación del Grupo de Estudios Penales, grupo de investigación de referencia reconocido por la Comunidad Autónoma de Aragón (BOA de 27 de marzo de 2017), cuyo Investigador Principal es el Prof. Dr. D. Miguel Ángel Boldova Pasamar (Catedrático de Derecho Penal de la Universidad de Zaragoza). 
pone de manifiesto cómo el Tribunal Supremo y, sobre todo, el Tribunal Constitucional han mutado la configuración de este tipo penal, añadiendo nuevos elementos a su injusto penal que no figuran actualmente en su tenor literal.

Palabras clave: terrorismo, enaltecimiento del terrorismo, art. 578 $\mathrm{CP}$, libertad de expresión, discurso del odio, jurisprudencia, interpretación judicial.

Abstract: The crime of praising terrorism was added in article 578 of the Spanish Criminal Code by 2000. It was not until 2015 when rulings started proliferating, some of them entailing considerable impact on media. This has developed an interesting jurisprudential doctrine that has generated important changes in the legal substance of the crime. This paper analyses how the Supreme Court and even more the Constitutional Court, have altered the structure of this crime by adding elements to the offence that are not currently encompassed in its literal meaning.

Keywords: terrorism, glorification of terrorism, art. $578 \mathrm{CP}$, freedom of expression, hate speech, jurisprudence, judicial interpretation.

\section{Introducción.}

El delito de enaltecimiento del terrorismo y de humillación de sus víctimas se introdujo, en el art. 578, en la reforma del Código Penal operada por la LO 7/2000, de 22 de diciembre, castigándose con una pena de prisión de uno a dos años «el enaltecimiento o la justificación por cualquier medio de expresión pública o difusión de los delitos comprendidos en los artículos 571 a 577 de este Código o de quienes hayan participado en su ejecución, o la realización de actos que entrañen descrédito, menosprecio o humillación de las víctimas de los delitos terroristas o de sus familiares» ${ }^{3}$.

El 16 de mayo de 2005 se realizó el Convenio del Consejo de Europa para la prevención del terrorismo (Convenio n. ${ }^{\circ} 196$ del Consejo de Europa), por el que los Estados Miembros se comprometieron a adoptar medidas eficaces para prevenir el terrorismo y para hacer frente, especialmente, a la provocación pública para cometer delitos terroristas, así como al reclutamiento y al adiestramiento con fines terroristas. En el ámbito de la Unión Europea se adoptó la Decisión Marco 2008/919/JAI

3 El texto original del Código Penal de 1995 no contemplaba la figura del enaltecimiento del terrorismo. Con anterioridad a la referida reforma, el art. $578 \mathrm{CP}$ regulaba los actos preparatorios punibles en los delitos de terrorismo y disponía que «la provocación, la conspiración y la proposición para cometer los delitos previstos en los artículos 571 a 577, se castigarán con la pena inferior en uno o dos grados a la que corresponda, respectivamente, a los hechos previstos en los artículos anteriores». 
del Consejo, de 28 de noviembre de 2008, la cual advertía que la amenaza terrorista había crecido y se había ido desarrollando rápidamente durante aquellos últimos años, con cambios en el modus operandi de los terroristas y sus partidarios, y se mostraba especialmente preocupada por la repercusión que podían tener las nuevas tecnologías, en especial Internet, en el avance y afianzamiento de los grupos terroristas y sus miembros ${ }^{4}$. Por su parte, la Resolución del Consejo de Seguridad de Naciones Unidas 2178, aprobada el 24 de septiembre de 2014, volvió a reafirmar que los actos de terrorismo son criminales e injustificables y constituyen una de las amenazas más graves para la paz y la seguridad internacionales, instando a los Estados Miembros a adoptar una serie de medidas con el fin de impedir que los grupos terroristas se arraiguen y encuentren refugio, para así enfrentar mejor la creciente amenaza que plantea el terrorismo ${ }^{5}$.

En nuestro país, el art. 578 CP fue objeto de una nueva reforma por la Ley Orgánica 2/2015, de 30 de marzo, la cual, con el fin de aplicar las medidas solicitadas por la referida Resolución 2178, introdujo diversas agravaciones de las penas que podían imponerse por la comisión este delito. Si bien la introducción de este delito en el año 2000 fue consecuencia de un acuerdo entre el PSOE y el $\mathrm{PP}^{6}$ con objeto de frenar e intentar acabar de una vez por todas con el terrorismo nacional, protagonizado principalmente por ETA, que aun asolaba nuestro país, la reforma operada en el año 2015, con un nuevo acuerdo entre dichos partidos políticos ${ }^{7}$, estuvo determinada por la nueva amenaza que supuso el terrorismo yihadista $^{8}$. Recientemente ha sido promulgada la Directiva (UE) 2017/541

4 Así, en su considerando número séptimo señalaba que «la presente Decisión establece la tipificación de delitos ligados a actividades terroristas con el fin de contribuir al objetivo político más general de prevenir el terrorismo mediante la reducción de la difusión de materiales que podrían inducir a las personas a cometer ataques terroristas».

5 En el catálogo de medidas que constituyen la parte dispositiva de esta Resolución, aparece en el punto sexto un recordatorio de la decisión contenida en la Resolución 1373 (2001) de que «todos los Estados Miembros velen por el enjuiciamiento de toda persona que participe en la financiación, planificación, preparación o comisión de actos de terrorismo o preste apoyo a esos actos».

6 "Acuerdo por las libertades y contra el terrorismo», firmado el 8 de diciembre de 2000.

7 «Acuerdo para afianzar la unidad en defensa de las libertades y en la lucha contra el terrorismo», firmado el 2 de febrero de 2015.

8 Hemos de recordar que la última víctima mortal del terrorismo etarra fue un policía francés y se produjo el 16 de marzo de 2010 en la localidad francesa de Dammarie-lèsLys. El 20 de octubre de 2011, ETA declaró un alto el fuego permanente que culminó en su desarme en el año 2017. Por su parte, el grupo terrorista GRAPO estaba inactivo desde el año 2007, cometiendo su último delito de sangre en el año 2006 en la localidad de Zaragoza. Aunque a comienzos del nuevo milenio se habían producido atentados yihadistas — cómo olvidar, entre otros, los trágicos sucesos acaecidos el 11 de septiembre de 2001 en Nueva York y el 11 de marzo de 2004 en la capital de nuestro país-, en los últimos años había crecido entre los países de Occidente la preocupación por encontrar la forma de prevenir y evitar nuevos ataques de estas organizaciones terroristas. Así, solo 
del Parlamento Europeo y del Consejo, de 15 de marzo de 2017, relativa a la lucha contra el terrorismo, la cual ha sido traspuesta a nuestro ordenamiento jurídico por la LO 1/2019, de 20 de febrero.

\section{Evolución jurisprudencial del art. 578 CP.}

Tras la reforma operada por la Ley Orgánica 2/2015, de 30 de marzo, el primer apartado del art. $578 \mathrm{CP}$ ha redactado de la siguiente manera: «El enaltecimiento o la justificación públicos de los delitos comprendidos en los artículos 572 a 577 o de quienes hayan participado en su ejecución ${ }^{9}$, o la realización de actos que entrañen descrédito, menosprecio o humillación de las víctimas de los delitos terroristas o de sus familiares, se castigará con la pena de prisión de uno a tres años y multa de doce a dieciocho meses...». Atendiendo al tenor literal del precepto, se infiere que tanto el ensalzamiento o justificación del terrorismo como la humillación de sus víctimas, han de realizarse mediante una conducta activa, ya sea de forma oral o escrita, no cabiendo la comisión omisiva ${ }^{10}$. No está prevista tampoco su comisión de forma imprudente.

dos meses antes de que entrase en vigor esta última reforma, el 7 de enero de 2015, se produjo el atentado contra Charlie Hebdo, semanario satírico francés, que fue asumido por Al Qaeda y dejó doce víctimas y once heridos. Este terrible suceso ayudó a disipar las dudas existentes en ese momento sobre la necesidad de endurecer el tratamiento penal de los delitos de terrorismo con el fin de lograr la tan deseada seguridad ciudadana, aunque ello supusiese limitar el ejercicio de ciertos derechos y libertades democráticos.

9 Como señala CAPITA REMEzAL, ha de interpretarse que resulta "punible tanto la apología de los autores del delito como de los partícipes, es decir, de todos los sujetos que hayan intervenido en cualquier delito de terrorismo ya realizado»; CAPITA REMEZAL, M., Análisis de la legislación penal antiterrorista, Colex, Madrid, 1. a ed., 2008, p. 165.

${ }_{10}$ El Auto de la Audiencia Nacional n. ${ }^{\circ}$ 38/2008, de 9 de julio (MP: S. F. J. Gómez Bermúdez) aclara que «el artículo $578 \mathrm{CP}$ contiene una norma prohibitiva; es decir, prohíbe una acción determinada. Es un delito que sólo puede cometerse mediante un comportamiento activo - un hacer, una acción-que contravenga la prohibición contenida en ésta. Dicho de otro modo, cometerá el delito quien viole con su comportamiento activo lo que el legislador prohíbe. A sensu contrario no se puede cometer el delito de que tratamos por mera omisión, no haciendo» (FJ 2. ${ }^{\circ}$ ). Asimismo, el auto señala que el art. 11 CP limita «la comisión por omisión a los delitos de resultado material y de peligro concreto, excluyéndose los de mera actividad como el de enaltecimiento del que tratamos» (FJ 5. ${ }^{\circ}$ ). Puede verse también el Auto del Juzgado Central de Instrucción n. ${ }^{\circ} 6$, de 14 de julio de 2008 (MP: P. R. Ruz Gutiérrez). En similares términos, la STS 587/2013, de 28 de junio (MP: J. M. Maza Martín, FJ $1 .^{\circ}$ ), indica «se trata de una figura delictiva consistente siempre en un comportamiento activo, excluyendo por tanto la comisión por omisión, tanto propia como impropia». Por tanto, el hecho de no cambiar el nombre de una calle (plaza o monumento) dedicada desde hace tiempo a una persona condenada por un delito de terrorismo, no puede integrar la conducta de enaltecimiento del terrorismo. Véase, al respecto, CANCIO MELIÁ, M. / DÍAZ LÓPEZ, J. A., ¿Discurso de odio y/o discurso terrorista? Música, guiñoles y redes sociales frente al artículo 578 del Código Penal, Aranzadi, Navarra, 1. ${ }^{a}$ ed., 2019, p. 176. 
Algunos autores han considerado que estas dos figuras delictivas, que cuentan con su propio contenido de injusto derivado de sus elementos configuradores, deberían haberse recogido en dos preceptos distintos o, al menos, en dos apartados diferentes dentro del art. $578 \mathrm{CP}^{11}$. Quizás el legislador consideró que era probable que estos dos tipos penales se cometiesen habitualmente de forma cumulativa, es decir, que aquellos individuos que manifestasen expresiones de elogio o justificación del terrorismo, también difundiesen mensajes que implicasen un ataque a la dignidad y honor de las víctimas que hubiesen sufrido las atrocidades del terrorismo, por lo que era conveniente incluirlas en un mismo apartado con el fin de no imponer una pena desproporcionada. No obstante, estimamos que la tipificación conjunta de ambos tipos penales en el mismo apartado del art. $578 \mathrm{CP}$ supone un defecto de técnica legislativa que dificulta su interpretación.

Ha de tratarse de una exaltación o justificación de hechos concretos de terrorismo ya acaecidos e incardinables en alguno de los delitos de terrorismo recogidos como tales en el Código Penal, sin que tengan que haberse perpetrado necesariamente en territorio español. No resultará punible el enaltecimiento de las virtudes privadas de sujetos condenados por delitos de terrorismo, sino únicamente su participación en tales hechos, ni la autoapología, es decir, el ensalzamiento o justificación de los propios actos de terrorismo perpetrados por el autor. Como señala LAMARCA PÉREZ, se trata de «un hecho impune cuyo desvalor debe quedar subsumido en el hecho principal realizado que se ensalza o justifica» ${ }^{12}$.

Aunque están a punto de transcurrir veinte años desde que este delito fue incorporado a nuestro Código Penal, ha sido durante los primeros

11 Puede verse, en este sentido, BERNAL DEL CASTILLO, J., «Observaciones en torno a la Ley Orgánica 7/2000 de 22 de diciembre, de modificación del Código penal en materia de terrorismo", en La Ley: Revista jurídica española de doctrina, jurisprudencia y bibliografía, n. ${ }^{\circ}$ 5, 2001, p. 1628. Crítica que reitera este autor en BERNAL DEL CASTILLO, J., "El enaltecimiento del terrorismo y la humillación a sus víctimas como formas del «discurso del odio»», en Revista de Derecho Penal y Criminología, $3{ }^{a}{ }^{a}$ Época, n. ${ }^{\circ}$ 16, 2016, p. 18. Postura que también ha sido defendida en algunas de las sentencias que han analizado este delito. Así, la STS 224/2010, de 3 de marzo (MP: J. Giménez García, FJ $3 .{ }^{\circ}$ ), señala que «tal vez la diferente acción típica y elementos que vertebran una y otra, hubiera aconsejado la tipificación separada en artículos diferentes». Como destaca CANCIO Melí, se trata de dos conductas que "poco o nada tienen que ver». A su parecer, con la tipificación conjunta de ambas figuras delictivas, el legislador "pretendía emboscar una criminalización discutible - la del enaltecimiento o justificación del terrorismo- en otra -la humillación de sus víctimas-que no lo parece». Véase, al respecto, CANCIO MELIÁ, M., Los delitos de terrorismo: estructura típica e injusto, Reus, Madrid, 1. a ed., 2010, p. 272; y CANCIO MELIÁ, M. / DÍAZ LÓPEZ, J. A., ¿¿Discurso de odio..., cit., pp. 155-156.

12 LAMARCA PÉREZ, C., "Legislación penal antiterrorista: análisis crítico y propuestas», en Azpilcueta cuadernos de derecho, n. ${ }^{\circ}$ 20, 2008, p. 211. Puede verse, en similares términos, CÁMARA ARROYO, S., «Delitos de odio: concepto y crítica: ¿límite legítimo a la libertad de expresión ?», en La Ley penal: revista de derecho penal procesal y penitenciario, n. ${ }^{\circ} 130,2018$, p. 17. 
años de esta segunda década, especialmente a partir del año 2015, cuando se ha producido un gran aumento del número de sentencias dictadas su comisión. Como se explicará a continuación, no hemos tenido ni por asomo una jurisprudencia constante y uniforme en esta materia, sino que ha ido evolucionando durante estos últimos años ${ }^{13}$. Por ello, resulta adecuado distinguir las distintas etapas por las que ha pasado nuestra jurisprudencia a la hora de aplicar e interpretar este delito, haciendo especial referencia a algunos de los casos más controvertidos y que han suscitado mayor repercusión mediática.

\section{Interpretación estrictamente literal.}

Durante la mayor parte del tiempo en que se ha enjuiciado este delito, la jurisprudencia ha adoptado una interpretación del mismo estrictamente literal, exigiendo únicamente la manifestación pública de un mensaje o expresión de ensalzamiento o justificación de alguno de los delitos comprendidos en los arts. 572 a $577 \mathrm{CP}$ o de quienes hayan participado en su ejecución ${ }^{14}$, o bien la realización de actos que impliquen descrédi-

13 Podemos encontrar excelentes estudios de dicha evolución jurisprudencial en CUERDA ARNAU, M.L., "Terrorismo y libertades políticas», en Teoría y derecho: revista de pensamiento jurídico, n. ${ }^{\circ}$ 3, 2008, pp. 33 y ss.; ALONSO RIMO, A., «Apología, enaltecimiento del terrorismo y principios penales», en Revista de Derecho Penal

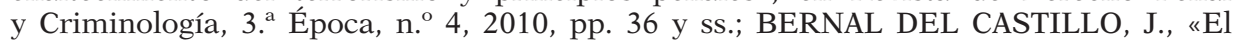
enaltecimiento del terrorismo...», cit., pp. 18 y ss.; TERUEL LOZANO, G.M., «Discursos extremos y libertad de expresión: un análisis jurisprudencial», en Revista de Estudios Jurídicos, n 17, 2017, pp. 12 y ss.; PASTRANA SÁNCHEZ, M.A., «Interpretación judicial del derecho y terrorismo: Especial referencia al enaltecimiento", en Revista de Derecho

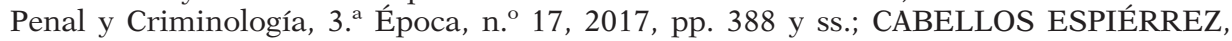
M.A., "Opinar, enaltecer, humillar: Respuesta penal e interpretación constitucionalmente adecuada en el tiempo de las redes sociales», en Revista española de derecho constitucional, n. ${ }^{\circ} 112,2018$, pp. 62 y ss.; GALÁN MUÑOZ, A., «El delito de enaltecimiento terrorista. ¿Instrumento de lucha contra el peligroso discurso del odio terrorista o mecanismo represor de repudiables mensajes de raperos, twitteros y titiriteros?», en Estudios penales y criminológicos, n. ${ }^{\circ}$ 38, 2018, pp. 272 y ss.; MIRÓ LLINARES, F., «Derecho penal y 140 caracteres. Hacia una exégesis restrictiva de los delitos de expresión», en Cometer delitos en 140 caracteres. El Derecho Penal ante el odio y la radicalización en Internet, Miró Llinares (dir.), Marcial Pons, Madrid, 1. ${ }^{a}$ ed., 2017, pp. 32 y ss.; y CANCIO MELIÁ, M. / DÍAZ LÓPEZ, J. A., ¿Discurso de odio..., cit., pp. 167 y ss.

14 En cuanto a la primera alternativa del art. $578 \mathrm{CP}$, la jurisprudencia entendía que los elementos que integraban esta infracción penal eran los siguientes: «1. ${ }^{\circ}$ La existencia de unas acciones o palabras por las que se enaltece o justifica el delito de terrorismo. Enaltecer equivale a ensalzar o hacer elogios, alabar las cualidades o méritos de alguien o de algo. Justificar aquí supone presentar o hacer aparecer como acciones lícitas y legítimas aquello que es un claro comportamiento criminal de carácter terrorista. $2 .^{\circ} \mathrm{El}$ objeto de tal ensalzamiento o justificación puede ser alguno de estos dos: a) cualquiera de las conductas definidas como delitos de terrorismo de los arts. 571 a 577; o b) cualquiera de las personas que hayan participado en la ejecución de tales comportamientos. Interesa recordar a este respecto que no es necesario identificar a una o a varias de tales personas, 
to, menosprecio o humillación de las víctimas de los delitos terroristas o de sus familiares.

Respecto del tipo penal de exaltación o justificación del terrorismo, no se requería que dicha conducta implicase una incitación directa o indirecta a la comisión de nuevos delitos de terrorismo ${ }^{15}$, ni que el dolo del autor abarcase más allá del propio elogio o exaltación del terrorismo. Los tribunales se encargaban de aclarar que esta figura delictiva constituye un delito autónomo respecto de la apología recogida en el art. $18 \mathrm{CP}$, la cual, como se dice en su precepto, solo es delictiva como forma de provocación y si por su naturaleza y circunstancias constituye una incitación directa a cometer un delito.

También se definía su naturaleza esencialmente dolosa o intencional, pero sin que fuese exigible que el autor actuase con una finalidad de provocar nuevos delitos terroristas, bastando con que objetivamente llevase a cabo una acción o difundiese un mensaje que supusiese una alabanza o justificación de las conductas definidas como delitos de terrorismo en el articulado del Código Penal o de quienes hubiesen participado en la ejecución de tales comportamientos delictivos ${ }^{16}$. La acusación no tiene que

pues puede cometerse también en referencia a un colectivo genérico de autores o copartícipes en esta clase de actos delictivos. $3 .^{\circ}$ Tal acción de enaltecer o justificar ha de realizarse por cualquier medio de expresión o difusión que otorgue cierta publicidad, como puede ser un periódico, un acto público o un lugar con numerosa concurrencia». Pueden verse, entre otras, las SsTS 149/2007, de 26 de febrero (MP: J. Delgado García, FJ 5. ${ }^{\circ}$ ); 299/2011, de 25 de abril (MP: F. Monterde Ferrer, FJ 1..$^{\circ}$ ); 587/2013, de 28 de junio (FJ 1. $\left.{ }^{\circ}\right) ; 481 / 2014$, de 3 de junio (MP: A. G. Jorge Barreiro, FJ 2. ${ }^{\circ}$ ); 843/2014, de 4 de diciembre (MP: C. Granados Pérez, FJ Único); 106/2015, de 19 de febrero (MP: J. Giménez García, FJ 3. ${ }^{\circ}$ ); y 948/2016, de 15 de diciembre (MP: A. G. Jorge Barreiro, FJ 4. ${ }^{\circ}$ ).

${ }_{15}$ Como hemos podido comprobar durante estos años, el hecho de que la tipificación del delito de enaltecimiento del terrorismo no requiriese una incitación directa o indirecta a la comisión de nuevos delitos terroristas, ha supuesto la condena por conductas de muy escasa gravedad, lo que ha supuesto una lamentable quiebra de los principios que rigen - o deberían regir - el Derecho Penal. De este modo, se ha llegado al extremo de condenar a una persona a un año de prisión y siete de inhabilitación absoluta simplemente por pintar con un rotulador el anagrama de ETA en una marquesina de la parada del autobús (SAN 3/2015, de 3 de febrero, MP: J. F. Martel Rivero) o en la fachada de un inmueble (SAN 17/2015, de 1 de julio, MP: A. L. Hurtado Adrián). Las mismas penas fueron impuestas por la SAN 26/2015, de 18 de septiembre (MP: C. P. González Pastor), a un individuo por pegar en una pared una pegatina de unos 10 × $6 \mathrm{~cm}$. que contenía el anagrama de dicha organización terrorista y la leyenda "ETA Bietan Jarrai» (ETA, adelante en las dos vías). Con la interpretación actual que se realiza de este tipo delictivo, estas conductas deberían considerarse atípicas, pues, como afirma PASTRANA SÁNCHEZ, "parece bastante improbable que la simple exhibición de un anagrama sea una línea discursiva suficiente para crear un ambiente social proclive a acciones terroristas, o que tal comportamiento eleve el riesgo ex ante de que se produzcan tales acciones»; PASTRANA SÁNCHEZ, M. A., "Apología del terrorismo y otros delitos afines: Evolución y tendencias en España y en el Perú», en Revista Derecho \& Sociedad, n. ${ }^{\circ}$ 52, 2019, p. 49.

16 La SAN 11/2007, de 19 de febrero (MP: F. J. Echarri Casi, FJ 3..$^{\circ}$ ), señala que «la figura recogida en el artículo 578 del Código Penal debe ser considerada como un delito autónomo, similar a la del artículo 18, pero sin la necesidad de la concurrencia 
probar el dolo requerido por este delito más allá de los propios mensajes o expresiones que hayan dado lugar al procedimiento judicial. Es decir, los magistrados no están obligados a realizar complejas argumentaciones respecto de la voluntad del autor cuando ésta puede inferirse de sus propias expresiones por poseer unas connotaciones tan alabadoras y ensalzadoras del terrorismo ${ }^{17}$. Asimismo, algunas sentencias destacan que no debe confundirse el dolo y el móvil interno que haya llevado al individuo a cometer esta infracción ${ }^{18}$.

La conducta típica de humillación de las víctimas ha tenido un menor desarrollo jurisprudencial con respecto del enaltecimiento o justificación del terrorismo, ya que esta última figura es la que más se ha aplicado por nuestros tribunales y, además, ha existido un mayor consenso en la doctrina respecto de la aceptación de la tipificación del segundo inciso

de los requisitos exigidos para la apología genérica. Para su tipicidad no es necesario que la expresión utilizada incite directa o indirectamente a la comisión de un delito, ni que el dolo del autor abarque más allá del propio elogio, es decir, no será preciso que el autor del delito de apología haya provocado o querido provocar la comisión de hechos delictivos como los que son objeto de la apología». En términos similares afirma la STS 224/2010, de 3 de marzo (FJ 3. ${ }^{\circ}$ ), que las características de este delito son «el tratarse de un comportamiento activo, que excluye la comisión por omisión, tanto propia como impropia, siendo un delito de mera actividad y carente de resultado material, y de naturaleza esencialmente dolosa o intencional». Por su parte, la STS 299/2011, de 25 de abril (FJ $\left.1 .^{\circ}\right)$, sigue esa misma línea interpretativa y dispone que «el enaltecimiento/ justificación del art. 578 constituye una forma autónoma de apología caracterizada por su carácter genérico y sin integrar una provocación ni directa ni indirecta a la comisión de un delito. La barrera de protección se adelanta, exigiéndose solamente la mera alabanza/ justificación genérica, bien de los actos terroristas o de quienes los efectuaron. [...] La propia Exposición de Motivos de la Ley apunta en esta dirección cuando se dice que «...las acciones que aquí se penalizan, con independencia de lo dispuesto en el art. 18 del CP»». Véase también, verbigracia, la STS 948/2016, de 15 de diciembre (FJ 4..$^{\circ}$ ).

17 En este sentido, la STS 948/2016, de 15 de diciembre (FJ 4. ${ }^{\circ}$ ), pone de manifiesto que «el tipo penal previsto en el art. 578 del texto punitivo no recoge expresa y específicamente en su dicción ningún elemento subjetivo, ya sea como componente del dolo o como integrante de un elemento subjetivo del injusto. Lo cual no significa que no se precise que la conducta tenga que resultar dolosa para su punición, sino que el dolo o cualquier elemento del injusto puede colegirse de los hechos declarados probados. [...] Las frases e imágenes que publicó el acusado resultan suficientemente expresivas de una voluntad concreta de alabar y justificar las acciones de organizaciones terroristas, y que persiguen la exaltación de los métodos terroristas. [...] Nos hallamos ante una clase de expresiones y de discurso en el que se utilizan unas palabras y unos sintagmas que, al albergar unas connotaciones tan alabadoras y ensalzadoras del terrorismo e hirientes para las víctimas, las simples locuciones utilizadas en la redacción de los mensajes transparentan sin necesidad de complejas argumentaciones cuál es el ánimo con que actuó el acusado al publicar en una red social las frases e imágenes descritas en la premisa fáctica».

18 Véase, al respecto, la STS 90/2016, de 17 de febrero (MP: J. R. Soriano Soriano, FJ $\left.1 .^{\circ}\right)$, la cual señala que «respecto al dolo o propósito del autor, la sentencia recurrida ha deslindado con pleno acierto los conceptos de dolo y móvil del delito, exigiendo el tipo penal el primero de ellos, cualquiera que sean las motivaciones que en su fuero interno pudieran llevar al recurrente a actuar del modo en que lo hizo. Las expresiones eran inequívocas y ensalzaban a los miembros de una organización terrorista, con conciencia y en circunstancias que iban a llegar al conocimiento de gran número de personas». 
del art. $578^{19}$. Este tipo penal, el cual afecta de forma directa al honor y dignidad de las víctimas de acciones terroristas y sus familiare ${ }^{20}$, no precisa de difusión pública, pues se consuma con la simple recepción efectiva de la ofensa por la víctima del terrorismo, o su familiar, que sufre un acto humillante o despreciativo ${ }^{21}$. Estamos también ante una conducta necesariamente activa y que requiere, a diferencia del enaltecimiento, un componente de idoneidad. En este caso, los actos de desprecio o humillación hacia las víctimas del terrorismo o sus familiares ${ }^{22}$ han de ser

19 Pueden verse, entre otros, FUSTER-FABRA TORRELLAS, J.M., Responsabilidad civil derivada de los actos de terrorismo, Atelier, Barcelona, 1. ${ }^{a}$ ed., 2001, p. 53; MORAL DE LA ROSA, J., Aspectos penales y criminológicos del terrorismo, Centro de Estudios Financieros, Madrid, 1. ${ }^{\text {a }}$ ed., 2005, p. 262; CANCIO MELIÁ, M., Los delitos de terrorismo..., cit., pp. 272-273; GARCÍA ALBERO, R., «Título XXII. Delitos contra el orden público», en Comentarios al Código Penal Español. Tomo II (Artículos 234 a DF. 7. ${ }^{a}$ ), Quintero Olivares (dir.), Aranzadi, Navarra, 6. ${ }^{\text {a }}$ ed., 2011, pp. 1749-1750; DOLZ LAGO, M.J., «Las actuaciones del Ministerio Fiscal en defensa de la dignidad de las Víctimas del Terrorismo, en El reconocimiento de las víctimas del terrorismo a través de la legislación y la jurisprudencia, Català i Bas (dir.), Cátedra de Derecho Autonómico Valenciano, Colección Cátedra Abierta n. ${ }^{\circ}$ 9, Valencia, 2013, p. 168; y MUÑOZ CONDE, F., Derecho Penal. Parte Especial, Tirant lo Blanch, Valencia, 21. ${ }^{a}$ ed., 2017, p. 790. En sentido contrario, véanse, verbigracia, CAPITA REMEZAL, M., Análisis de la legislación..., cit., pp. 171 y ss.; LAMARCA PÉREZ, C., "Legislación penal...», cit., p. 211; CUERDA ARNAU, M.L., "Delitos de terrorismo: aspectos sustantivos y procesales», en El nuevo panorama del terrorismo en España: perspectiva penal, penitenciaria y social, Juanatey Dorado (dir.), Ed. Universidad de Alicante, 1. ${ }^{a}$ ed., 2013, p. 119; CABELLOS ESPIÉRREZ, M.A., "Opinar, enaltecer...», cit., p. 83; y CARBONELL MATEU, J.C., "Crítica a los sentimientos como bien jurídicopenal: El enaltecimiento del terrorismo y la humillación a las víctimas «más allá de la provocación y la injuria»», en Terrorismo, Sistema Penal y Derechos Fundamentales, Alonso Rimo (dir.), Tirant lo Blanch, Valencia, 2018, pp. 353 y ss.

20 Véanse, al respecto, LLOBET ANGLI, M., Derecho Penal del terrorismo. Límites de su punición en un Estado democrático, La Ley, Madrid, 1. ${ }^{a}$ ed., 2010, pp. 452 y ss.; CASTELLVÍ MONSERRAT, C., «Terrorismo (arts. 571-580)», en Manual de Derecho Penal. Parte Especial. Doctrina y jurisprudencia con casos solucionados. Tomo 1, Corcoy

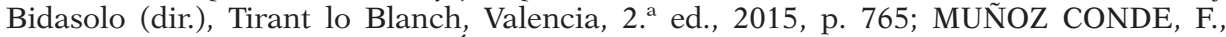
Derecho Penal..., cit., p. 790; y GÓMEZ NAVAJAS, J., «Sentencia de la Audiencia Nacional (Sala de lo Penal), de 15 de noviembre de 2016 [ROJ SAN 4038/2016]: absolución del delito de humillación de las víctimas del terrorismo», en Ars Iuris Salmanticensis: AIS: revista europea e iberoamericana de pensamiento y análisis de derecho, ciencia política y criminología, Vol. 5, n. ${ }^{\circ}$ 1, 2017, p. 377.

21 Véase, en este sentido, la STS 752/2012, de 3 de octubre (MP: J. Saavedra Ruiz, FJ 3. $\left.{ }^{\circ}\right)$.

22 La STS 656/2007, de 17 de julio (MP: J. R. Berdugo Gómez de la Torre, FJ 4. ${ }^{\circ}$ ), que conoció del caso del grupo de música «Soziedad Alkoholika», estableció un concepto restrictivo de víctimas o familiares a los efectos de la aplicación de este delito al indicar que «serian víctimas «directas» las personas que sufran lesiones corporales graves o daños graves en su salud física o mental como consecuencia de cualquier delito terrorista; y en caso de muerte, a titulo de víctimas «indirectas» diversos familiares (cónyuge o persona que viniera conviviendo con el fallecido de forma permanente, hijos o padres, según los casos)». Resulta muy acertada la crítica de CARBONELl MATEU respecto de los problemas que plantea la falta de delimitación del ámbito de parentesco exigible a efectos de tipificación de este delito, por la inseguridad jurídica que aquéllo puede conllevar. Véase, al respecto, CARBONELL MATEU, J.C., «Crítica a los sentimientos...», cit., p. 343. 
idóneos, subjetiva y objetivamente, para afectar a su honor y dignidad. No es necesario que se trate de una ofensa que, por su naturaleza, efectos y circunstancias, sea tenida en el concepto público por grave, como sí se exige respecto del delito de injurias en el art. $208 \mathrm{CP}$.

No es necesario que el sujeto actúe con un ánimo específico de atacar al honor de las víctimas o sus familiares (animus iniuriandi), sino que, como señala la STS 846/2015, de 30 de diciembre (MP: A. del Moral García, FJ 4. ${ }^{\circ}$ ), «basta con conocer el carácter objetivamente humillante y vejatorio de las expresiones consideradas aislada y contextualmente, y asumirlo y difundirlo haciéndolo propio. [...] Basta un dolo genérico. Cosa distinta es que el contexto, el momento, el tono, las circunstancias hayan de tenerse en cuenta al evaluar la idoneidad del texto para evidenciar humillación o desprecio» ${ }^{23}$. Cabe destacar que el art. 578 CP dispone que la segunda figura delictiva que recoge en su tenor literal consiste en «la realización de actos que entrañen...», es decir, que ha de tratarse de más de un acto que implique descrédito, menosprecio o humillación de las víctimas de los delitos terroristas o de sus familiares, no bastando solamente un mensaje o expresión que lesione su dignidad y honor ${ }^{24}$.

23 En el mismo sentido pueden verse, entre otras, las SsTS 820/2016, de 2 de noviembre (MP: A. del Moral García), y 948/2016, de 15 de diciembre. Respecto de esta cuestión, puede acudirse a lo señalado por MAYO CALDERón respecto de los delitos de injuria, quien afirma que «los elementos subjetivos de lo injusto adicionales al dolo solo han de exigirse cuando sean absolutamente necesarios para delimitar lo injusto penal de lo injusto de otros sectores del ordenamiento jurídico o para delimitar los distintos tipos penales entre sí y ello no es necesario en el delito de injuria. En este delito es posible delimitar la conducta punible atendiendo a su carácter objetivamente injurioso y a que el sujeto conozca y quiera llevar a cabo una acción o expresión que menoscabe la fama de una persona o atente contra su propia estimación, sin necesidad de exigir, como elemento subjetivo de lo injusto adicional y diferente al dolo, el ánimo de enjuriar»; MAYO CALDERÓN, B., "Delitos contra el honor», en Derecho Penal. Parte Especial. Conforme a las leyes orgánicas 1 y 2/2015, de 30 de marzo, Boldova Pasamar (coord.), Comares, Granada, 1. ${ }^{a}$ ed., 2016, pp. 293-294.

24 En este sentido, conviene traer a colación la SAN 35/2016, de 15 de noviembre (MP: M. A. Barreiro Avellaneda), que conoció del mediático caso de Guillermo Zapata, concejal de Madrid que fue acusado de haber incurrido en la conducta de humillación de las víctimas del terrorismo por un comentario que publicó en su cuenta de Twitter, en enero de 2011, en el que decía que "han tenido que cerrar el cementerio de las niñas de Alcaser para que no vaya Irene Villa a por repuestos». La Audiencia Nacional fundamentó su absolución en que no concurría la continuidad o reiteración necesaria que exige el tipo penal, ya que el acusado solo había publicado un mensaje que pudiese calificarse como humillación de las víctimas del terrorismo (su siguiente comentario en clave de humor se refería a las víctimas del holocausto). Además, los magistrados tampoco apreciaron una actuación de desprecio por su parte, sino que sus comentarios, aunque desafortunados, se difundieron en el curso de conversaciones sobre debates a modo de chistes macabros, utilizando la identidad de víctimas de hechos delictivos. 


\section{Criterio interpretativo del Tribunal Constitucional.}

Aquella solución interpretativa estrictamente literal encontraba difícil encaje en nuestro marco constitucional y suponía, sin duda, una vulneración del derecho fundamental a la libertad de expresión que no podía resultar legítima, ni siquiera para hacer frente al fenómeno del terrorismo. El Tribunal Constitucional comenzó a precisar los elementos configuradores del delito de enaltecimiento del terrorismo en su ATC 4/2008, de 9 de enero, en el que desestimó el recurso de amparo interpuesto por Iñaki de Juana Chaos, exmiembro de la banda terrorista ETA condenado por un delito de amenazas no condicionales a grupos de personas en concurso ideal con otro de enaltecimiento del terrorismo por dos artículos periodísticos publicados en el Diario Gara en diciembre de $2004^{25}$.

En este auto, el Tribunal Constitucional comprueba si se ha vulnerado el derecho a la libertad de expresión del recurrente y, para ello, trae a colación su reciente STC 235/2007, de 7 de noviembre (MP: E. Gay Montalvo), en la cual se analiza la constitucionalidad de los tipos penales referidos a la negación y difusión de ideas que justifiquen el genocidio y se establece la doctrina de que solo puede ser constitucional la punición de las conductas de justificación del genocidio cuando constituyan una incitación, aun indirecta, a la comisión de nuevos delitos. Siguiendo la línea interpretativa introducida por aquella sentencia ${ }^{26}$, los magistrados consideran que la condena de este sujeto por un delito de enaltecimiento o justificación del terrorismo no supone una vulneración de su derecho a la libertad de expresión, ya que el legislador penal puede sancionar la alabanza o justificación de los delitos de terrorismo cuando opere como incitación indirecta a su comisión ${ }^{27}$.

25 En cuanto al análisis del caso De Juana Chaos, pueden verse, entre otros, ARIAS CASTAÑO, A., "Amenazas, Enaltecimiento del Terrorismo y Libertad de Expresión: El caso De Juana Chaos», en Indret: Revista para el Análisis del Derecho, n. ${ }^{\circ} 4,2007$, pp. 4 y ss.; y GARCÍA DE BLANCO, V., «Delitos de terrorismo, cumplimiento de pena y separación de poderes: el caso "De Juana Chaos»», en Icade: Revista de las Facultades de Derecho y Ciencias Económicas y Empresariales, n. ${ }^{\circ} 72,2007$, pp. 234 y ss.

26 Respecto de la influencia que ha tenido la STC 235/2007, de 7 de noviembre, en la interpretación del tipo penal de enaltecimiento o justificación del terrorismo, véanse, especialmente, RAMOS VÁZQUEZ, J.A., "Presente y futuro del delito de enaltecimiento y justificación del terrorismo», en Anuario da Facultade de Dereito da Universidade da Coruña, n. ${ }^{\circ}$ 12, 2008, pp. 787 y ss.; y ALONSO RIMO, A., «Apología, enaltecimiento»..., cit., pp. 57 y ss.

27 De este modo, el ATC 4/2008, de 9 de enero (FJ 7. ${ }^{\circ}$ ), señala que «tampoco la condena por el delito de enaltecimiento o justificación de delitos de terrorismo o de sus autores (art. $578 \mathrm{CP}$ ) supone una vulneración del derecho a la libertad de expresión, pues, como se afirma en la STC 235/2007, de 7 de noviembre, en relación con los delitos de genocidio, «la especial peligrosidad de delitos tan odiosos y que ponen en riesgo la esencia misma de nuestra sociedad» - cosa que debe afirmarse ahora también de los delitos de terrorismo«permite excepcionalmente que el legislador penal sin quebranto constitucional castigue la justificación pública de ese delito, siempre que tal justificación opere como incitación 
En este supuesto, el Tribunal Constitucional estima que dicha provocación indirecta a la comisión de ulteriores delitos terroristas es constatable en las cartas que originaron la condena del recurrente, puesto que en ellas se realiza una valoración positiva de la conducta criminal de los presos de ETA y se justifican sus actos violentos, con expresiones amenazantes que contienen una incitación, aun indirecta, a la violencia terrorista $^{28}$.

Pese a que el ATC 4/2008, de 9 de enero, había introducido esta pauta interpretativa en el enjuiciamiento de las conductas de ensalzamiento o justificación del terrorismo, durante los siguientes años se fueron sucediendo una serie de sentencias que obviaron la exigencia de tal incitación indirecta a la violencia terrorista. No obstante, el Tribunal Constitucional se volvió a pronunciar al respecto en su STC 112/2016, de 20 de junio (MP: J. A. Xiol Ríos), en la cual conoció de un recurso de amparo interpuesto por Tasio Erkizia, miembro histórico de la izquierda abertzale, contra las sentencias de la Audiencia Nacional y del Tribunal Supremo que lo habían condenado por enaltecimiento del terrorismo ${ }^{29}$, y aprovechó esta ocasión para precisar el contenido y los límites del derecho a la libertad de expresión y su eventual conflicto con la aplicación e interpretación del delito de enaltecimiento del terrorismo.

indirecta a su comisión» (FJ 9)». La STC 235/2007, de 7 de noviembre, realizaba así una interpretación para salvar la legítimidad constitucional de la conducta de justificación del genocidio. Sin embargo, respecto del delito de negación del genocidio, esta sentencia declara su inconstitucionalidad precisamente por carecer de ese elemento de incitación en su tipificación, puesto que estima que solo los actos de justificación del genocidio pueden operar como una incitación indirecta a la comisión de delitos.

28 En palabras de los magistrados, «esta provocación indirecta a la violencia es constatable en el escrito que originó la condena de su autor. Como ya ha quedado expresado por referencia a la motivación de la Sentencia recurrida, en el mismo se concitan tanto una consideración positiva de la conducta de los presos de ETA en cuanto a los execrables hechos que les llevaron a tal situación penitenciaria, al afirmar que están secuestrados por un sistema autoritario y que no se resocializan porque tienen razón, como la ya analizada expresión que amenaza de un modo creíble con una conducta violenta a determinados colectivos que están relacionados con el encarcelamiento de aquellos presos. La justificación de quienes actuaron con extraordinaria violencia en relación precisamente con esta actuación violenta y la adición a la misma de una expresión amenazante permiten afirmar que el escrito contiene la provocación a la violencia, siquiera indirecta, pero referida a la comisión de gravísimos delitos, que impide su cobertura en el ejercicio legítimo de la libertad de expresión» (FJ 7..$^{\circ}$.

29 Tasio Erkizia había sido condenado por dichos tribunales por su participación como principal orador en un acto celebrado en el año 2008, en la localidad de Arrigorriaga (Vizcaya), en recuerdo y loa del responsable de la organización terrorista ETA José Miguel Beñaran, alias «Argala», quien había sido asesinado treinta años antes en la localidad francesa de Angelu. En este acto, Tasio Erkizia pidió «una reflexión [para] escoger el camino más idóneo, el camino que más daño le haga al Estado, que conduzca a este pueblo a un nuevo escenario democrático» y terminó con los gritos de "Gora Euskal Herria askatuta», «Gora Euskal Herria euskalduna» y "Gora Argala» (Viva Euskal Herria libre, Viva Euskal Herria vasca, Viva Argala). 
En su sentencia, el Tribunal Constitucional destaca tanto el carácter preeminente que tiene el derecho a la libertad de expresión en los sistemas democráticos, como su carácter limitado cuando entra en conflicto con otros derechos o intereses constitucionales, como sucede, por ejemplo, con aquellas expresiones que son manifestación del llamado «discurso del odio» y que cabe interpretar como incitaciones a la violencia, discriminación contra colectivos, etc. Para solventar el conflicto existente entre la libertad de expresión y este delito, los magistrados traen a colación la referida STC 235/2007, de 7 de noviembre, y acuden al art. 5 del Convenio del Consejo de Europa para la prevención del terrorismo, hecho en Varsovia el 16 de mayo de $2005^{30}$, y al art. 3.1.a) de la Decisión Marco 2002/475/JAI del Consejo, de 13 de junio de 2002, sobre la lucha contra el terrorismo (modificada por la Decisión Marco 2008/919/JAI del Consejo, de 28 de noviembre de 2008) ${ }^{31}$.

Tras tomar en consideración sus anteriores resoluciones y la normativa europea, el tribunal concluye que para que el delito de enaltecimiento del terrorismo sea compatible con el estándar del derecho de la libertad de expresión, debe imponerse la siguiente exigencia: «la sanción penal de las conductas de exaltación o justificación de actos terroristas o de sus autores requiere, como una manifestación del discurso del odio, una situación de riesgo para las personas o derechos de terceros o para el propio sistema de libertades» ${ }^{32}$.

De este modo, el Tribunal Constitucional consolida en su STC 112/2016, de 20 de junio, un nuevo criterio a valorar a la hora de decidir si un mensaje incurre en un delito de enaltecimiento del terrorismo, puesto que además de implicar una incitación, incluso indirecta, a la

30 El art. 5 de dicho Convenio establece lo siguiente: «1. A los efectos del presente Convenio, se entenderá por "provocación pública para cometer delitos terroristas» la difusión o cualquier otra forma de puesta a disposición del público de mensajes con la intención de incitar a cometer delitos terroristas, cuando ese comportamiento, ya preconice directamente o no la comisión de delitos terroristas, cree peligro de que se puedan cometer uno o varios delitos. 2. Cada Parte adoptará las medidas necesarias para tipificar como delito, de conformidad con su derecho interno, la provocación pública para cometer delitos terroristas tal como se define en el apartado 1, cuando se cometa ilegal e intencionadamente» (la cursiva es nuestra).

31 Tras la referida modificación, el art. 3.1.a) de la Decisión Marco 2002/475/JAI dispone que se entenderá por provocación a la comisión de un delito de terrorismo «la distribución o difusión pública, por cualquier medio, de mensajes destinados a inducir a la comisión de cualesquiera de los delitos enumerados en el artículo 1, apartado 1, letras a) a h), cuando dicha conducta, independientemente de que promueva o no directamente la comisión de delitos de terrorismo, conlleve el riesgo de comisión de uno o algunos de dichos delitos (la cursiva es nuestra)».

32 De esta forma, el Tribunal Constitucional legitima la punición de este tipo penal, declarando que no infringe la libertad de expresión, al considerarlo una manifestación del «discurso del odio» y recuerda que la Constitución no ampara la difusión de mensajes o expresiones que inciten o justifiquen el odio basado en la intolerancia, o que alienten o promuevan el uso de la violencia para imponer criterios propios. 
comisión de nuevos delitos de terrorismo, habrá de tratarse de una conducta que, desde una perspectiva ex ante, aumente el riesgo de que se produzcan tal clase de delitos, sin que sea necesario que lleguen a cometerse, pues estamos ante un delito de peligro y no de resultado. Con la tipificación de este delito se procura evitar la creación de un determinado caldo de cultivo, una atmósfera o ambiente social proclive a acciones terroristas, que aumente la probabilidad de que resurja o aumente la violencia terrorista.

No obstante, pese a sentar esta importante doctrina jurisprudencial, la sentencia termina denegando el amparo solicitado por el recurrente al entender que su conducta no podía ser considerada como un legítimo ejercicio de este derecho, por tratarse de una expresión de odio basado en la intolerancia y manifestado a través de un nacionalismo agresivo, con inequívoca presencia de hostilidad hacia otros individuos ${ }^{33 / 34}$.

Aunque el Tribunal Constitucional había consolidado tal criterio interpretativo del primer inciso del art. $578 \mathrm{CP}$, no fueron pocas las resoluciones judiciales que obviaron la necesidad de que concurriese aquel elemento de riesgo para poder dictar una sentencia condenatoria. Así, por ejemplo, pocos meses después de que se dictase aquella sentencia, la SAN 29/2016, de 8 de noviembre (MP: F. Grande-Marlaska Gómez),

33 La STC 112/2016, de 20 de junio (FJ 6..$^{\circ}$ ), considera que en este supuesto hubo una instigación a la violencia, concluyendo que «incitar supone siempre llevar a cabo una acción que ex ante implique elevar el riesgo de que se produzca tal conducta violenta. Desde esta última perspectiva, acciones como las que nos ocupan crean un determinado caldo de cultivo, una atmósfera o ambiente social proclive a acciones terroristas, antesala del delito mismo, singularmente si se tienen en cuenta las circunstancias en las que cursaron los hechos: fue un acto público, previamente publicitado mediante carteles pegados en las calles, en un contexto en el que la actividad terrorista seguía siendo un importante problema social. Por consiguiente, es incuestionable que, para un espectador objetivo, la conducta del recurrente era idónea para contribuir a perpetuar una situación de violencia».

$34 \mathrm{La}$ antedicha sentencia cuenta con un voto particular formulado por el magistrado Juan Antonio Xiol Ríos, quien consideró que la Sala debería haber estimado el recurso de amparo interpuesto por Tasio Erkizia, ya que se había vulnerado su derecho a la libertad de expresión. Aunque este magistrado muestra su acuerdo con la opinión mayoritaria de considerar que las acciones o conductas que inciten, aun de forma indirecta, a la violencia no deben quedar amparadas por aquel derecho, advierte que el Tribunal debería haber realizado un estudio más profundo de los elementos que posibilitan la represión penal de conductas de ensalzamiento o justificación de la violencia terrorista desde la perspectiva del derecho a la libertad de expresión, puesto que en este caso no concurrían dichos elementos. Además, Xiol Ríos hace referencia al factor del contexto en el que se difunde el mensaje, al afirmar que «otro de los elementos que han sido relevantes en las valoraciones realizadas por el Tribunal Europeo de Derechos Humanos es que la conducta desarrollada coincidiera en el tiempo con actos terroristas [...] o que se acreditara un contexto de violencia en que esa manifestación hubiera tenido alguna influencia». Este magistrado trae a colación las SsTEDH de 25 de noviembre de 1997, as. Zana c. Turquía, § 56; 28 de septiembre de 1999, as. Öztürk c. Turquía, § 69; y 2 de octubre de 2008, as. Leroy c. Francia, $\S 45$. 
impuso a un ciudadano las penas de un año de prisión y siete años de inhabilitación absoluta al entender que había cometido un delito de enaltecimiento del terrorismo, sin que se hiciese referencia alguna en su fundamentación a la cuestión de si la conducta desplegada por el acusado había sido adecuada para propiciar o alentar, aun de manera indirecta, la referida situación de riesgo ${ }^{35}$. Por su parte, la STS 706/2017, de 27 de octubre (MP: J. R. Soriano Soriano), pese a traer a colación el citado art. 5 del Convenio del Consejo de Europa para la prevención del terrorismo, que exige que concurra en el autor una intención de incitar a cometer delitos terroristas y que su conducta preconice la comisión de tal clase de delitos, obvia completamente la doctrina constitucional, puesto que admite la condena de un sujeto al entender que su conducta era plenamente ajustada al tipo previsto en el art. 578, sin realizar valoración alguna de la idoneidad peligrosa ínsita en la difusión de sus mensajes a través de Twitter ${ }^{36}$.

Si bien es cierto que se han suscitado un menor número de casos relacionados con la conducta típica de humillación de las víctimas del terrorismo, hemos sido testigos de algunas condenas que han causado un gran revuelo mediático y han sido objeto de severas críticas por parte de nuestra doctrina más especializada. Una de las máximas exponentes de estos sucesos fue la SAN 9/2017, de 29 de marzo (MP: J. F. Martel Rivero), que condenó a las penas de un año de prisión y siete años de inhabilitación absoluta a una joven universitaria, Cassandra Vera ${ }^{37}$, al en-

35 Ese fue el motivo por el que el magistrado Ramón Sáez Valcárcel formuló un voto particular a esta sentencia, al considerar que «es preciso constatar una acción de enaltecimiento que ex ante implique un incremento del peligro de que se produzcan atentados terroristas, es decir la conducta ha de ser idónea para propiciar o contribuir a perpetuar una situación de violencia terrorista». Además, este magistrado estimó que la Sala debería haber tenido en cuenta la inexistencia de un contexto de violencia terrorista relacionado con los GRAPO como un importante motivo en favor de la absolución del acusado. Como veremos más adelante, esta sentencia fue revocada por la STS 378/2017, de 25 de mayo (MP: L. Varela Castro).

36 Esta sentencia ha resultado polémica porque amplía considerablemente la responsabilidad penal al concluir que es suficiente con retuitear un mensaje para que pueda apreciarse el tipo de enaltecimiento del terrorismo. En este procedimiento, el acusado había aducido que las imágenes y vídeos reproducidos no formaban parte de un mensaje, razonamiento o argumentación propios, sino que existían previamente en los medios, ya que el término retuitear significa reproducir lo que preexistió. Sin embargo, los magistrados rechazaron sus argumentos e indicaron que el tipo penal del art. 578 no exige «que el acusado asuma como propio, razone o argumente la imagen y su mensaje, ni tampoco que sea el recurrente el que lo haya creado, basta que de un modo u otro accedan a él, y les de publicidad, expandiendo el mensaje a gran cantidad de personas» (FJ 1. ${ }^{\circ}$ ). Esto supone una peligrosa ampliación del ámbito de aplicación de este delito.

37 Puede verse un excelente comentario del caso Cassandra, así como de los casos de los titiriteros, Strawberry y Valtònyc en CANCIO MELIÁ, M. / DÍAZ LÓPEZ, J. A., ¿Discurso de odio..., cit., pp. 185 y ss. Respecto de los casos Cassandra y Strawberry, véase también MIRÓ LLINARES, F., «Ofender como acto de terrorismo. A propósito de los casos «César Strawberry» y «Cassandra Vera»», en Liber Amicorum. Estudios Jurídicos 
tender que había incurrido en esta conducta por publicar en su perfil de Twitter, entre los años 2013 y 2016, doce chistes de humor negro sobre el atentado que terminó con la vida del Almirante Luis Carrero Blanco en $1973^{38}$.

Aunque los chistes versaban sobre un atentado ocurrido en el año 1973, es decir, habiendo transcurrido más de cuarenta años, la Audiencia Nacional entendió que ello no debía tener relevancia alguna en este caso, puesto que «la lacra del terrorismo de ETA persiste, aunque con menor intensidad, y las víctimas del terrorismo constituyen una realidad incuestionable, que merecen respeto y consideración, con independencia del momento en que se perpetró el sangriento atentado» (FJ 1..$\left.^{\circ}\right)^{39}$. Pese a que Cassandra había manifestado que había escrito esos chistes en tono humorístico y en clave irónica, la Sala concluye que se trata de unas expresiones que encierran un injustificable desprecio hacia las víctimas del terrorismo y que precisamente una de las facetas de la humillación consiste en la burla, no recreada con chistes macabros con un sujeto pasivo indeterminado, sino referidos a una persona concreta a quien se identifica con su nombre y apellidos ${ }^{40}$.

No obstante, la STS 95/2018, de 26 de febrero (MP: A. G. Jorge Barreiro), estima, con buen rigor, que los chistes que dieron lugar a este procedimiento judicial no contienen ningún mensaje hiriente o vejatorio contra la persona de Carrero Blanco o sobre algún aspecto concreto de su vida privada, sino que se limitan a hacer mofa o sarcasmo de la forma

en Homenaje al Prof. Dr. Dr. h.c. Juan M. ${ }^{a}$ Terradillos Basoco, De la Cuesta Aguado (coord.), Tirant lo Blanch, Valencia, 1. ${ }^{a}$ ed., 2018, pp. 1437 y ss.

38 Algunos de los chistes publicados por Cassandra en su cuenta de Twitter fueron los siguientes: "ETA impulsó una politica contra los coches oficiales combinada con un programa espacial», "Película: «A tres metros sobre el cielo.» Producción: ETA films, Director: Argala. Protagonista: Carrero Blanco. Género: Carrera espacial», "Kissinger le regaló a Carrero Blanco un trozo de la luna, ETA le pagó el viaje a ella», "Elecciones el día del aniversario del viaje espacial de Carrero Blanco. Interesante», “¿Carrero Blanco también regresó al futuro con su coche?».

39 CARBonell Mateu se pregunta si la irrelevancia del momento historíco en el que ocurrió el atentado objeto de burla por los chistes publicados por Cassandra, pese a que han transcurrido cuarenta y cuatro años y se han producido unos cambios políticos significativos, podría ser también aplicable, por ejemplo, «a los asesinatos del general Prim o de Viriato, pastor lusitano»; CARBONELL MATEU, J.C., «Crítica a los sentimientos...», cit., p. 351.

40 Cabe destacar que la defensa aportó como prueba un manifiesto denominado "Carrrero como síntoma», firmado por 245 profesores universitarios de Derecho Penal, alarmados por el hecho de que se pretendiese condenar a una joven única y exclusivamente por hacer humor satírico sobre la muerte de un gobernante de la Dictadura, así como una carta abierta de la propia nieta de Carrero Blanco, Lucía Carrero-Blanco, en la que expresaba su preocupación ante la desproporción y el disparate que suponía la decisión de la Fiscalía de la Audiencia Nacional de solicitar la imposición de una pena de prisión para esta estudiante. Sin embargo, los magistrados estimaron que dichas pruebas no poseían virtualidad alguna para exonerar a la acusada de responsabilidad penal. 
en el que se produjo el atentado ${ }^{41}$. Respecto del contexto en que se difundieron sus mensajes, los magistrados entienden que el atentado sufrido por Carrero Blanco, aun tratándose de una gravísima tragedia, puede considerarse un suceso histórico cuyo comentario en clave de humor no puede tener la misma transcendencia que un acontecimiento reciente ${ }^{42}$.

Mientras que Cassandra Vera había sido condenada por la Audiencia Nacional y finalmente absuelta por el Tribunal Supremo, César Montaña Lehman, cuyo nombre artístico es César Strawberry, sufrió el efecto contrario, puesto que, pese a ser en principio absuelto por aquel tribunal del delito de enaltecimiento del terrorismo y de humillación de sus víctimas del que venía siendo acusado, fue finalmente condenado por el Tribunal Supremo ${ }^{43}$. La SAN 20/2016, de 18 de julio (MP: M. F. Fernández Prado), absolvió al acusado por estimar que había quedado acreditado que sus manifestaciones artísticas estaban impregnadas de un sentido metafórico y ficticio, que no pretendían ser un reflejo de la realidad, sino que buscaban realizar una crítica a la realidad social y política existente en la actualidad. Se llega a la conclusión de que ninguno de los comentarios publicados por César Strawberry es constitutivo de delito, puesto que no existe una defensa de la violencia, sino que se busca, desde el sarcasmo y la ironía, provocar el efecto contrario ${ }^{44}$.

41 La sentencia señala que su conducta se había centrado en «repetir chistes ya conocidos en las redes sociales en los que se juega en clave de humor con la forma singular en que se perpetró el atentado. Se publicitan pues palabras o imágenes en las redes sociales relacionadas casi todas ellas con el hecho de que el vehículo oficial saliera por los aires a unos 35 metros de altura hasta caer en una repisa del patio interior de un edificio situado en la calle por donde circulaba» (FJ 2..$^{\circ}$.

42 Aunque la Sala reputa que la conducta de hacer mofa de aquella tragedia es reprochable tanto desde un prisma social como incluso moral, a través de una interpretación constitucional del art. 578 termina declarando que la recurrente "ni dio muestras con su conducta de que estaba pretendiendo incitar a la violencia abusando de un ejercicio ilícito de la libertad de expresión, ni provocaba al odio hacia grupos determinados, ni tampoco se valía de mofarse del atentado contra un expresidente de Gobierno ocurrido hace más de cuarenta años con intención de justificarlo o de incitar a nuevos atentados» (FJ 2. $\left.{ }^{\circ}\right)$.

43 Entre los años 2013 y 2014, César Strawberry, cantante y letrista de los grupos de rap-metal Def Con Dos y Strawberry Harcdcore, publicó en su perfil de Twitter: «el fascismo sin complejos de Aguirre me hace añorar hasta los GRAPO", "a Ortega Lara habría que secuestrarle ahora", "Street Fighter, edición post ETA: Ortega Lara versus Eduardo Madina», "Franco, Serrano Suñer, Arias Navarro, Fraga, Blas Piñar... Si no les das lo que a Carrero Blanco, la longevidad se pone siempre de su lado", "Cuántos deberían seguir el vuelo de Carrero Blanco».

${ }_{44}$ La sentencia refleja, en los hechos probados, que «las letras de sus canciones tienen un marcado tono provocador, irónico y sarcástico, empleando recursos propios de las historias de terror y acción para envolver el mensaje de fondo. En sus manifestaciones artísticas mantiene un tono crítico con la realidad social y política, tratando que el público comprenda el sentido metafórico y ficticio que envuelve sus obras, respecto al concepto de fondo siempre de carácter pacífico y exclusivamente cultural». La Audiencia Nacional realiza un riguroso análisis de cada uno de los mensajes publicados por aquel músico. Así, por ejemplo, respecto del comentario «el fascismo sin complejos de Aguirre me hace 
Sin embargo, a raíz del recurso de casación interpuesto por el Ministerio Fiscal, la STS 4/2017, de 18 de enero (MP: M. Marchena Gómez), decidió revocar la absolución de César Strawberry y lo condenó a la pena de un año de prisión, con seis años y seis meses de inhabilitación absoluta. En este supuesto, la acusación pública alega que la Audiencia Nacional había errado al confundir el dolo con el móvil del autor y sostiene que para la concurrencia de este delito no se exige un dolo redoblado como elemento subjetivo, sino que es suficiente la concurrencia de un dolo básico. El Tribunal Supremo acepta tal argumento y lleva a cabo una peligrosa interpretación de este delito al indicar que «el art. 578 del CP sólo exige el dolo, esto es, el conocimiento de los elementos que definen el tipo objetivo. En el presente caso, tener plena conciencia y voluntad de que se está difundiendo un mensaje en el que se contiene una evocación nostálgica de las acciones violentas de un grupo terrorista. [...] La estructura típica del delito previsto en el art. 578 del CP no precisa la acreditación de con qué finalidad se ejecutan los actos de enaltecimiento o humillación» (FJ 3. ${ }^{\circ}$. . De este modo, la finalidad con la que se difunden los mensajes sería completamente indiferente y se podría condenar a una persona incluso aunque se pudiese probar en el juicio que ésta no tenía intención alguna de enaltecer o justificar de terrorismo, ni de despreciar o humillar a sus víctimas o familiares. Es decir, se prescinde erróneamente de la voluntad con la que el autor ejecuta el hecho delictivo ${ }^{45}$.

añorar hasta los GRAPO», los magistrados afirman que «no puede entenderse que con esta manifestación pretenda el acusado hacer apología del terrorismo y provocar el discurso del odio, sino una crítica hacia el extremismo de cualquier signo, llevando su ironía a comparar un partido político con un grupo terrorista» (FJ 3..$^{\circ}$. Respecto del tuit que hacía referencia a José Antonio Ortega Lara, funcionario secuestrado por ETA durante 532 días entre 1996 y 1997 ( "a Ortega Lara habría que secuestrarle ahora»), la Sala considera que no parece que el acusado «trate de elogiar a la banda terrorista ETA que tuvo secuestrado a Ortega Lara, ni tampoco que trate de humillarle o vejarle en algún modo, por más que pueda parecer en extremo desacertado el comentario» (FJ 3. ${ }^{\circ}$ ).

${ }_{45} \mathrm{Al}$ respecto, PASTRANA SÁNCHEZ afirma acertadamente que «realmente resulta difícil comprender este razonamiento; pues, por ejemplo, si diera igual el contenido de la voluntad con la que se ejecutan los hechos, ello querría decir que si un sujeto agrede a otro propinándole una patada, con un ánimo, a lo sumo, de lesionar, pero finalmente el sujeto atacado muere, habría que castigar por homicidio doloso en lugar de calificar, como normalmente se hace, tales hechos como lesiones dolosas en concurso con homicidio imprudente (dado que el ánimo del sujeto era lesionar — animus laedendi- y no matar animus necandi-). Si en tales casos se entiende, correctamente, que la voluntad de matar (o al menos, la aceptación de la posibilidad de que se esté matando — dolo eventual—) no es un móvil ajeno al tipo de homicidio, sino una parte fundamental de su elemento subjetivo (que no debe abarcar solo el acto consciente de la agresión, sino también la producción del resultado típico), no llega a comprenderse, en definitiva, las razones que motivan una interpretación contraria del elemento subjetivo del tipo de enaltecimiento del terrorismo, pues también en tales casos debe requerirse la voluntad de enaltecer (o al menos, la aceptación de la posibilidad de que se esté enalteciendo — dolo eventual—)»; PASTRANA SÁNCHEZ, M.A., "Interpretación judicial...», cit., pp. 390-391. 
Teniendo ello en cuenta, la Sala realiza su propio examen de los comentarios publicados por Strawberry y llega a una conclusión inversa con respecto a lo manifestado por la Audiencia Nacional, al entender que pueden subsumirse perfectamente en las conductas tipificadas en el art. 578. Cabe destacar que los magistrados reconocen que dicho artículo ha de ser interpretado conforme a la doctrina constitucional, pero de ningún modo indagan sobre la posible peligrosidad que pudiese tener la conducta del recurrente para la creación de un determinado caldo de cultivo, una atmósfera o ambiente social proclive a acciones terroristas. Esto es, no se valora en ningún momento si el comportamiento desplegado por César Strawberry ha sido idóneo para elevar el riesgo de que se cometan nuevos delitos de terrorismo ${ }^{46}$.

\section{Relevancia del contexto y de la finalidad del autor.}

Recientemente algunas sentencias se han alejado de la tónica interpretativa adoptada por nuestra jurisprudencia mayoritaria y se han preocupado por realizar un estudio más profundo de los casos, haciendo un especial análisis del contexto en que se producen los hechos y de la finalidad o intención con la que actúa el autor. Este cambio jurisprudencial se vio en gran parte motivado por la entrada en vigor de la Directiva (UE) 2017/541, del Parlamento Europeo y del Consejo, de 15 de marzo, relativa a la lucha contra el terrorismo ${ }^{47}$. Conforme a dicho texto, para poder tipificar las conductas de provocación pública a la comisión de un delito de terrorismo se exige que aquéllas impliquen el riesgo de que pueda perpetrarse tal clase de delitos y que dicho riesgo sea valorado

46 Esta resolución judicial cuenta con un voto particular formulado por el magistrado Perfecto Andrés Ibáñez, quien comienza señalando que «lo que convierte en criminales las conductas de referencia es su aptitud para estimular la práctica de las acciones descritas en los arts. 571 a $577 \mathrm{CP}$, legitimándolas de algún modo, se hace preciso que aquellas guarden una mínima relación contextual y de efectiva funcionalidad con estas, de manera que quienes ejecutan actos de terrorismo puedan beneficiarse de ellas o rentabilizarlas en términos de apoyo, generación de consenso o de prestigio social. Y en el caso de las relativas a las víctimas, debería tratarse de formulaciones capaces de hacer que una víctima hipotética pudiera considerarse directamente concernida y sentirse vilipendiada por ellas». Este magistrado, coincidiendo con lo expresado por la sentencia de primera instancia, estima que los tuits publicados por Strawberry no poseen la mínima consistencia discursiva y no pasan de ser meros exabruptos sin mayor recorrido, que se agotan en sí mismos. Si bien considera su conducta moralmente reprochable, sostiene que carece de la menor posibilidad de conexión práctica con algún tipo de actores y de acciones técnicojurídicamente susceptibles de ser consideradas terroristas, especialmente por el contexto en el que fueron difundidas sus expresiones.

47 Puede verse un estudio de cómo afecta la entrada en vigor de dicha directiva a la aplicación e interpretación del art. 578 CP en MUÑOZ CUESTA, J., «Interpretación del enaltecimiento de terrorismo conforme a la Directiva UE 2017/541, de 18 de marzo», en Revista Aranzadi Doctrinal, n. ${ }^{\circ}$ 8, 2017. 
suficientemente por los órganos judiciales nacionales atendiendo a los distintos elementos a que hace referencia esta directiva ${ }^{48}$.

Debemos comenzar citando la STS 378/2017, de 25 de mayo, que conoció del recurso de casación interpuesto contra la SAN 29/2016, de 8 de noviembre, la cual había condenado a un joven a las penas de un año de prisión y siete años de inhabilitación absoluta por publicar, en el año 2012, diversos comentarios en su perfil de Facebook ${ }^{49}$. Además de acoger expresamente la antedicha doctrina constitucional, el Tribunal Supremo, sustentando su argumentación en la Directiva (UE) 2017/541, estima que el órgano judicial debe acreditar que la finalidad o intención del autor ha sido precisamente incitar o provocar, incluso de forma indirecta, la comisión de nuevos delitos de terrorismo, y que su comportamiento ha sido idóneo para originar la situación de riesgo, aunque dicho riesgo haya de entenderse en abstracto, no referido a un concreto delito de terrorismo ${ }^{50}$.

Esta sentencia alude al contexto de ausencia de violencia terrorista relacionado con los GRAPO como uno de los motivos en que fundamentar la absolución del recurrente, al entender que, además de que no cons-

48 La Directiva (UE) 2017/541, en su considerando n. ${ }^{\circ} 10$, dispone que «los delitos de provocación pública a la comisión de un delito de terrorismo comprenden, entre otros, la apología y la justificación del terrorismo o la difusión de mensajes o imágenes, ya sea en línea o no, entre ellas las relacionadas con las víctimas del terrorismo, con objeto de obtener apoyo para causas terroristas o de intimidar gravemente a la población. Esta conducta debe tipificarse cuando conlleve el riesgo de que puedan cometerse actos terroristas. En cada caso concreto, al examinar si se ha materializado ese riesgo se deben tener en cuenta las circunstancias específicas del caso, como el autor y el destinatario del mensaje, así como el contexto en el que se haya cometido el acto. También deben considerarse la importancia y la verosimilitud del riesgo al aplicar la disposición sobre provocación pública de acuerdo con el Derecho nacional». Su artículo quinto señala que «los Estados miembros adoptarán las medidas necesarias para garantizar que se tipifique como delito, cuando se cometa intencionadamente, el hecho de difundir o hacer públicos por cualquier otro medio, ya sea en línea o no, mensajes destinados a incitar a la comisión de uno de los delitos enumerados en el artículo 3, apartado 1, letras a) a i), siempre que tal conducta preconice directa o indirectamente, a través, por ejemplo, de la apología de actos terroristas, la comisión de delitos de terrorismo, generando con ello un riesgo de que se puedan cometer uno o varios de dichos delitos» (la cursiva es nuestra).

49 Sus publicaciones fueron las siguientes: «Viva los G.R.A.P.O», "Llamame terrorista si grito VIVA LOS GRAPO!!», "iOjalá vuelvan los GRAPO, y os pongan de rodillas!», "Feliz. día del país Vasco Euskadi Ta Askatasuma».

50 De esta forma, la sentencia destaca «la relevancia a efectos de tipificación, como cuestión de legalidad ordinaria, pero bajo exigencias constitucionales, de la acreditación de con qué finalidad o motivación se ejecutan los actos de enaltecimiento o humillación. Y de la valoración sobre el riesgo que se crea con el acto imputado. Por más que tal riesgo haya de entenderse en abstracto como «aptitud» ínsita en la actuación imputada, pero no referida a un concreto delito de terrorismo, acotado en tiempo, espacio, por referencia a personas afectadas» (FJ 2. ${ }^{\circ}$ ). Asimismo, advierte que "una cosa es proclamar, incluso vociferar, lo que el sujeto «siente», es decir sus deseos o emociones, exteriorizándolos a «rienda suelta» y otra cosa que tal expresión se haga, no para tal expresión emotiva, sino, más allá, para la racional finalidad de procurar que el mensaje, al menos indirectamente, mueva a otros a cometer delitos de terrorismo» (FJ 2. $\left.{ }^{\circ}\right)$. 
taba si sus mensajes habían sido leídos por terceras personas, el contexto en el que fueron difundidos ocasionaba que su conducta careciese de la idoneidad necesaria para incitar, aun de forma indirecta, la comisión de nuevos actos terroristas ${ }^{51}$. Por ello, concluye que de los hechos probados no se infiere que se haya producido una mutación del estado de cosas tal que la realización de los delitos de terrorismo vea aumentada la eventualidad de su acaecer ni en un mínimo ápice ${ }^{52}$.

Esta senda interpretativa fue seguida tan solo dos meses después por la STS 560/2017, de 13 de julio (MP: J. R. Berdugo Gómez de la Torre), que absuelve al recurrente al advertir que en la sentencia de instancia no había quedado acreditado que el autor hubiese actuado con la intención de incitar efectiva y realmente la comisión de delitos de terrorismo; y la STS 600/2017, de 25 de julio (MP: J. A. Sánchez Melgar), la cual enjuicia un supuesto de enaltecimiento del terrorismo surgido a raíz de unos mensajes publicados Twitter en el año 2014 ${ }^{53}$, en el que la Audiencia Nacional había absuelto al acusado e incluso había reflejado en los hechos probados que «no consta actuación alguna posterior a la publicación de cada uno de los twits, por parte de personas o grupos de personas en reacción de apoyo o solidaridad con los mismos». En este caso, el Tribunal Supremo vuelve a dictaminar que no ha acreditado que la actuación del acusado fuese realizada con la intención de provocar la perpetración de actos de carácter terrorista y que, además, tampoco se ha probado que las expresiones controvertidas, aun siendo de mal gusto, hayan entrañado el riesgo que exigen tanto la jurisprudencia constitucional como la normativa europea.

51 El Tribunal Supremo acoge las razones expuestas en el voto particular formulado por el magistrado Sáez Valcárcel a la sentencia de instancia, indicando que debe tenerse en cuenta lo siguiente: «a) inexistencia de un contexto de violencia terrorista relacionado con los «Grapo». Esta organización desapareció hace años y no comete atentados $\bigotimes$ b) las publicaciones que se atribuyen al acusado, en el año 2012, no coincidían con acciones de esta organización terrorista, y c) en ninguna de las tres publicaciones de la página de Facebook del acusado aparece la réplica de algún internauta. Lo que significa que no consta si dichos mensajes han sido leídos por otras personas, ni siquiera que tenga seguidores» $\left(\mathrm{FJ} 2 .^{\circ}\right)$.

52 ALONSO RIMO afirma que la STS 378/2017, de 25 de mayo, va ciertamente más allá en términos garantistas que la propia STC 112/2016, de 20 de junio, en la que se apoya y que la doctrina del discurso del odio en los términos en que la recoge en general nuestro Tribunal Constitucional y considera que la interpretación que realiza dicha sentencia del art. $578 \mathrm{CP}$ es la más razonable. Véase, al respecto, ALONSO RIMO, A., "¿Impunidad general de los actos preparatorios? La expansión de los delitos de preparación», en Indret: Revista para el Análisis del Derecho, n..$^{\circ}$ 4, 2017, p. 42.

53 Entre las publicaciones del acusado constan las siguientes: "La lucha es el único camino. Viva Euskal Herria libre y socialista», "EH BILDU condena el ataque a un cajero de Kutxabank. ¿Cómo quieren que se defienda a la ciudadanía de la banca? ¿pidiéndolo por favor? Fariseos», "Yo sí odio al PP y al PSE. A mi sí me gustaría ver a cada uno de ellos colgado de un pinar completo». 
Cabe destacar también la reciente STS 52/2018, de 31 de enero (MP: A. Palomo del Arco), que confirma el fallo absolutorio dictado por la SAN 12/2017, de 21 de marzo (MP: J. R. Sáez Valcárcel), que conoció del procedimiento judicial que se llevó a cabo contra el abogado Arkaitz Terrón, acusado de exaltar el terrorismo en varios mensajes publicados en su cuenta de Twitter ${ }^{54}$. La SAN 12/2017, de 21 de marzo $^{55}$, realiza un riguroso examen de cada uno de los mensajes que la acusación pública entiende que ensalzan el terrorismo y concluye que objetivamente esos micromensajes no enaltecen ni justifican el terrorismo porque no incitan ni instigan a la violencia terrorista, ni siquiera indirectamente, y tampoco generan un peligro de comisión de actos violentos ${ }^{56}$. Los magistrados subrayan que la ausencia de riesgo alguno se evidencia en el hecho de que sus tuits solamente fueron detectados a raíz de las investigaciones

54 Arkaitz Terrón había escrito, entre otras, las siguientes frases: «Tras conocer que el Ayuntamiento de Madrid homenajeará de nuevo a Carrero Blanco sólo puedo decir una cosa ESKERRIK ASKO ARGALA!», "No entiendo por qué la placa a Carrero no se la ponen los productores de cava. El día que ETA lo hizo volar se descorcharon muchas botellas", "Hace 35 años el BVE asesinó a quien nos libró de Carrero Blanco...", «Juan Carlos Primero, más alto que Carrero!!...».

${ }_{55}$ La Audiencia Nacional considera adecuado incorporar al debate un estándar autorizado del Derecho internacional para la interpretación de los delitos de incitación al terrorismo: los denominados Principios de Johannesburgo sobre la Seguridad Nacional, la Libertad de Expresión y el Acceso a la Información, aprobados el 1 de octubre de 1995, por un grupo de expertos en Derecho internacional, seguridad nacional y derechos humanos. Así, de conformidad con su principio número sexto, la libertad de expresión solo se podrá castigar como una amenaza a la seguridad nacional si el Gobierno puede demostrar que la expresión tiene la finalidad de incitar a la violencia inminente, puede dar lugar a tal violencia y existe una conexión directa e inmediata entre la expresión y la probabilidad o el acontecimiento de tal violencia. En su principio número séptimo declara que el ejercicio pacífico del derecho a la libertad de expresión no se considerará una amenaza a la seguridad nacional ni estará sometido a restricción o sanción alguna. Los Principios de Johannesburgo fueron acogidos por el Informe del Relator Especial sobre la promoción y protección del derecho a la libertad de opinión y de expresión, Frank La Rue (Asamblea General de las Naciones Unidas), elaborado el 16 de mayo de 2011. En su ordinal $36^{\circ}$ manifiesta que «la protección de la seguridad nacional o la lucha contra el terrorismo no pueden aducirse para justificar la restricción del derecho a la libertad de expresión, a no ser que el Gobierno pueda demostrar que: a) la expresión tiene por objetivo instigar a la violencia inmediata; b) es probable que instigue a ese tipo de violencia; y c) existe una relación directa e inmediata entre la expresión y la posibilidad de que se produzca ese tipo de violencia».

56 La SAN 12/2017, de 21 de marzo (FJ 2. ${ }^{\circ}$ ), advierte que la incitación o instigación requiere de un llamamiento a la acción, sea explícito o implícito, que ha de implicar, desde una perspectiva ex ante, un incremento del riesgo de que se produzca la conducta violenta, es decir, «una probabilidad de que el discurso genere el tipo de acción que reivindica. La alabanza sin un elemento adicional que convoque a la acción, por muy próximo que se encuentre a la incitación, no es incitación, ni siquiera indirecta». Por consiguiente, las conductas de simple elogio o justificación del terrorismo que no cuenten con aquella probabilidad de generar un incremento del riesgo de que se produzca la temida violencia terrorista, habrán de considerarse, en todo caso, atípicas. 
policiales. Hasta entonces habían pasado desapercibidos, no habían tenido impacto alguno en la opinión pública ${ }^{57}$.

Cobra una gran trascendencia la referencia que hace la sentencia a la forma en la que fueron detectados aquellos tuits, puesto que la gran mayoría de los procedimientos judiciales sobre enaltecimiento del terrorismo de los que hemos sido testigos durante estos últimos años han sido consecuencia directa de las denominadas «Operaciones Araña» desarrolladas por la Guardia Civil ${ }^{58}$. Evidentemente, de seguirse este razonamiento en el resto de procedimientos judiciales, las sentencias condenatorias dictadas en esta materia se verían considerablemente reducidas.

La absolución del acusado se apoya también en la circunstancia de que los mensajes son difundidos en un contexto de inexistencia de violencia terrorista relacionado con ETA, volviendo a incidir esta sentencia en que ha de tenerse en cuenta en la valoración judicial que esta organización terrorista no realiza en la actualidad actividades armadas ${ }^{59}$. La STS 52/2018, de 31 de enero, concuerda totalmente con los argumentos aducidos por la Audiencia Nacional y dictamina que el comportamiento de Arkaitz Terrón es atípico, puesto que sus tuits, que traslucen un ánimo crítico, no son potencialmente aptos para incrementar, ni siquiera de forma mínima, el peligro de comisión de delitos terroristas.

57 La sentencia indica que aquellos mensajes «son expresión de opiniones o deseos, actos de comunicación no seguidos de incitación a la acción, porque no contienen llamamiento a la violencia terrorista ni han generado riesgo alguno para las personas, ni los derechos de terceros ni para el orden jurídico. La mejor demostración de la ausencia de riesgo alguno es que los tuits solo fueron detectados cuando los investigadores policiales realizaron prospecciones en la red social, que se convirtieron en destinatarios de los mensajes. Por lo tanto, no habían tenido impacto alguno en la opinión pública» (FJ 2..$^{\circ}$ ).

58 Nos referimos a las cuatro «Operaciones Araña» que ha realizado durante estos últimos años la Guardia Civil, bajo la coordinación y supervisión de la Audiencia Nacional, y que han consistido en revisar perfiles y cuentas abiertas en las redes sociales en busca de personas que pudiesen haber incurrido en alguna de las conductas tipificadas en el art. $578 \mathrm{CP}$. En dichas operaciones han sido detenidas un total de 76 personas, unas cifras nada desdeñables. Mira Benavent afirma que estas investigaciones policiales poseen un carácter prospectivo que acarrea su ilegalidad. Véase, al respecto, MIRA BENAVENT, J., «El delito de enaltecimiento del terrorismo, el de humillación a las víctimas del terrorismo y la competencia de la Audiencia Nacional: ni delito, ni terrorismo, ni competencia de la Audiencia Nacional», en Terrorismo, Sistema Penal y Derechos Fundamentales, Alonso Rimo (dir.), Tirant lo Blanch, Valencia, 2018, p. 321. Véase también, verbigracia, PASTRANA SÁNCHEZ, M. A., "Apología del terrorismo...», cit., p. 49.

59 Así, los magistrados expresan que «en el examen de conductas incriminadas como enaltecedoras o justificadoras del terrorismo ha de tenerse en cuenta, aquí lo ponemos de manifiesto, que el fenómeno del terrorismo local (frente al de alcance internacional) cuyo protagonista era ETA se ha transformado de manera radical antes de la emisión de los mensajes, pues la organización terrorista ha abandonado desde hace más de cinco años la realización de actividades armadas, y se encuentra en fase de liquidación» (FJ 2. ${ }^{\circ}$ ). 
Aunque, en proporción, los supuestos de ensalzamiento o justificación del terrorismo yihadista ${ }^{60}$ han sido mucho menores que respecto del terrorismo nacional ${ }^{61}$, debemos indicar que las resoluciones judiciales dictadas por enaltecimiento de esta clase de terrorismo han adaptado sus argumentaciones a los cambios jurisprudenciales que se han producido en esta materia, exigiendo, en un primer momento, solamente la manifestación pública de un mensaje de exaltación o justificación de las actividades desplegadas por estas organizaciones terroristas o sus miem$\operatorname{bros}^{62}$, hasta requerir la concurrencia de una incitación, aun indirecta, a la perpetración de nuevos actos de violencia terrorista y la creación de un riesgo abstracto de que puedan cometerse tales actos en el futuro ${ }^{63}$.

60 Debemos advertir que, como señala la STS 556/2006, de 31 de mayo (MP: F. Monterde Ferrer), el propio significado de 'yihad' no es siempre y necesariamente violento, sino que para que estemos ante un hecho delictivo, al mencionar la yihad ha de precisarse que se alude a su acepción de guerra contra todos aquellos que no compartan sus creencias, sus prácticas religiosas y su forma de vida en cualquier parte del mundo.

61 Como advierte BERNAL DEL CASTILLO, normalmente los actos de apología del terrorismo yihadista no se limitan a la simple divulgación general del mensaje enaltecedor, sino que suelen dirigirse a fines más amplios de captación, adoctrinamiento o reclutamiento de nuevos miembros (art. $575 \mathrm{CP}$ ), o bien se trata de actos de exaltación de la violencia yihadista que constituyen verdaderas formas de participación en grupos u organizaciones terroristas, porque no se limitan a elogiarlas, sino que también colaboran con ellas (art. $577 \mathrm{CP}$ ). Asimismo, en un gran número de casos, las manifestaciones ensalzadoras del radicalismo yihadista constituyen en realidad actos de provocación directa a la comisión de delitos terroristas (art. 579 CP). Véase, al respecto, BERNAL DEL CASTILLO, J., "El enaltecimiento del terrorismo...», cit., p. 39. Ello ha conllevado que el número de casos enjuiciados de enaltecimiento de esta clase de terrorismo conforme al art. $578 \mathrm{CP}$ haya sido mucho menor que respecto del terrorismo nacional. De acuerdo a los datos proporcionados por Amnistía Internacional en su informe titulado «Tuitea... si te atreves. Cómo las leyes antiterroristas resitringuen la libertad de expresión en España» (marzo de 2018, p. 15), entre 2011 y 2017, el 92\% de las personas procesadas en aplicación del art. 578 fueron acusadas de enaltecimiento de grupos armados internos, no extranjeros, como ETA y GRAPO, y de humillar a sus víctimas. En el mismo periodo, se dictaron solo 14 de un total de 117 sentencias en relación con el ensalzamiento de grupos armados extranjeros, como el grupo que se autodenomina Estado Islámico.

${ }^{6}$ Así, por ejemplo, la SAN 32/2015, de 23 de noviembre (MP: R. J. de Prada Solaesa), condenó a un individuo por enaltecimiento del terrorismo a raíz de un vídeo que publicó en su canal de YouTube sobre Osama Bin Laden, en el que se hacía una alabanza y propaganda de ideas de carácter terrorista. En este supuesto, los magistrados no verificaron si la conducta desplegada por el acusado había originado una situación de riesgo para las personas, derechos de terceros o el propio sistema de libertades. Esta sentencia fue confirmada por la STS 400/2016, de 11 de mayo.

63 La STS 354/2017, de 17 de mayo (MP: A. Palomo del Arco), que estima el recurso de casación interpuesto contra la SAN 39/2016, de 30 de noviembre (MP: C. E. Bayarri García), la cual condenó a un individuo por un delito de autoadoctrinamiento con finalidad terrorista (art. 575.2 CP), modifica su fallo para castigarlo, en su lugar, por un delito de enaltecimiento del terrorismo. El recurrente había sido condenado por aquel delito a causa de difundir en Internet una gran cantidad de mensajes de contenido yihadista radical y en defensa de los fines del Estado Islámico. Los magistrados inciden en la importancia que ha tenido en esta materia tanto la doctrina constitucional como la Directiva (UE) 2017/541, de 15 de marzo, y manifiestan que la actuación del recurrente ha consistido en una aprobación y justificación de la guerra que mantiene el Estado Islámico 


\section{Contrapuesta valoración del riesgo: conflicto con el derecho de creación artística.}

A la luz de estas últimas sentencias parecía que se iba a disminuir drásticamente el número de condenas impuestas por nuestros tribunales en aplicación del art. $578 \mathrm{CP}^{64}$. Sin embargo, como es habitual en esta materia, no se ha seguido una interpretación uniforme de aquel precepto y de los elementos o requisitos que legitiman su punición, por lo que también contamos con un conjunto de resoluciones judiciales que siguiendo la misma doctrina constitucional y aplicando la antedicha normativa europea, han llegado a conclusiones opuestas a las sentencias mencionadas, al estimar que los mensajes o discursos controvertidos sí habían causado un riesgo abstracto de perpetración de nuevos actos

y de su expansión a través del terror y las armas contra todo infiel en cualquier lugar. Así, señalan que «existe una celebración del terror y de la violencia como forma de operar del Estado Islámico y por ende de sus integrantes, frente a judíos, chiíes y todo aquél que no sea musulmán suní y una inequívoca justificación de su expansión contra los 'infieles', que colman el comportamiento típico del art. 578, no solo ya por la incitación indirecta que conllevan, sino por el potencial riesgo que para la comisión de delitos terroristas, dada la eficacia de este método yihadista en indeterminados recipiendarios individuales, como resulta de la experiencia de diversos atentados atribuidos con acuñada expresión periodística a «lobos solitarios»» (FJ $\left.4 .^{\circ}\right)$. En el mismo sentido, pueden verse, verbigracia, las SsTS 221/2017, de 29 de marzo (MP: P. Llarena Conde), y 47/2019, de 4 de febrero (MP: J. A. Sánchez Melgar). Por su parte, la STS 72/2018, de 9 de febrero (MP: A. Martínez Arrieta), aplicando también dicha doctrina constitucional, absuelve al recurrente del delito de enaltecimiento del terrorismo por el que había sido condenado como consecuencia de una serie de mensajes publicados en su cuenta de Twitter, al entender que sus expresiones de loa al terrorismo yihadista habían sido demasiado genéricas, sin concretar el destinatario del acto que se alaba o de la figura que se pretende reivindicar, tratándose más bien de una manifestación de deseos que carece de la intensidad necesaria para implicar un peligro para el bien jurídico protegido.

64 En esa misma línea puede citarse también la SAN 6/2018, de 1 de marzo (MP: J. de Diego López), que absolvió a una joven tuitera que había publicado ciertos mensajes como «Rey muerto, abono para el huerto», "Gora ETA»y «Soy del GRAPO, puta España», así como la SAN 28/2018, de 26 de julio (MP: N. Poveda Peñas), que absolvió a seis jóvenes integrantes del colectivo «Straight Edge Madrid» del delito de enaltecimiento del terrorismo del que habían sido acusados por publicar ciertos videos e imágenes en sus redes sociales. En ambos casos, los magistrados consideraron que no había quedado acreditado que se hubiese generado el riesgo de perpetración de actos de terrorismo, siquiera en abstracto, que exige la jurisprudencia constitucional y la normativa europea. Por su parte, la STS 646/2018, de 14 de diciembre (MP: A. Martínez Arrieta, FJ único), para dictimar que las expresiones de exaltación del terrorismo de ETA proferidas por el acusado no debían ser objeto de reproche penal, tiene en cuenta su escasa difusión y el leve impacto causado, así como la circunstancia de que «la llamada a la acción no es real, no es seria, en la medida en que la apelación se hace a organizaciones terroristas, felizmente, desaparecidas». Asimismo, la reciente SAN 2/2019, de 17 de enero (MP: A. M. Riera Ocariz, FJ $3 .^{\circ}$ ), que conoce de otro caso más de ensalzamiento de la organización terrorista ETA, tiene en cuenta en favor de dictar una sentencia absolutoria, que el escaso número de mensajes del acusado, realizados entre los años 2012 a 2015, «son publicados cuando dicha banda se encontraba ya inactiva». Véanse también las SsAN 21/2019, de 20 de abril (MP: C. E. Bayarri García), y 10/2019, de 8 de julio (MP: J. R. Navarro Miranda). 
de terrorismo. Estos últimos supuestos han provocado un gran revuelo mediático y han suscitado numerosas críticas doctrinales, ya que no solo se ha visto afectada la libertad de expresión, sino también el derecho de creación artística, puesto que algunos de los sujetos condenados por este delito han sido cantantes, interpretes del género musical «hip-hop», quienes han visto cómo sus canciones y expresiones artísticas les han acarreado severas penas de prisión ${ }^{65}$.

Antes de analizar aquellos supuestos, debemos aludir al sorprendente caso de los titiriteros, considerado por PORTILLA CONTRERAS como «Uno de los mayores ataques a la libertad de expresión que se recuerdan en España» ${ }^{66}$. El 5 de febrero de 2016 la compañía de teatro "Títeres desde abajo», formada por los actores Alfonso Lázaro y Raúl García, representó en Madrid su obra «La bruja y don Cristóbal», en la cual, de acuerdo a las declaraciones de los asistentes, se representaban diversas escenas como el ahorcamiento de un muñeco de un juez, la violación y el apuñalamiento de una monja con un crucifijo y el apaleamiento de varios policías, exhibiéndose un cartel con la expresión "Gora ALKA-ETA». El Auto del Juzgado Central de Instrucción n. ${ }^{\circ} 2$ de la Audiencia Nacional, de 6 de febrero de 2016, estimó que tales hechos constituían un delito de enaltecimiento del terrorismo y un delito cometido con ocasión del ejercicio de los derechos fundamentales y de las libertades públicas (art. $510.2 \mathrm{CP}$ ), y decretó la prisión provisional de los dos titiriteros, quienes permanecieron en esta situación durante cinco días ${ }^{67}$.

65 En este sentido, Mira Benavent muestra su preocupación por el hecho de que este delito haya «dejado de aplicarse estrictamente a esos entornos políticos o ideológicos que directamente prestan apoyo político o proporcionan la justificación ideológica para la comisión de delitos de terrorismo, para comenzar a aplicarse a personas que no pertenecen ni tienen vinculación alguna con organizaciones terroristas ni con sus entornos; pues en efecto: los habituales clientes de los delitos de enaltecimiento y humillación a las víctimas del terrorismo son hoy mayoritariamente personas o grupos que simplemente simpatizan, muestran nostalgia por grupos terroristas que dejaron de existir hace ya tiempo o hacen humor negro con las víctimas del terrorismo. [...] Se acaba condenando a personas o grupos de música que manifiestan a través de las redes sociales o de la letra de sus canciones sus mensajes heterodoxos o de carácter antisistema»; MIRA BENAVENT, J., «El delito de enaltecimiento...», cit., p. 320.

66 Puede verse el análisis crítico que realiza este autor del caso de los titiriteros en PORTILLA CONTRERAS, G., «El retorno de la censura y la caza de brujas anarquistas», en Cometer delitos en 140 caracteres. El Derecho Penal ante el odio y la radicalización en Internet, Miró Llinares (dir.), Marcial Pons, Madrid, 1. ${ }^{a}$ ed., 2017, pp. 88 y ss.

67 El Auto del Juzgado Central de Instrucción, de 6 de febrero de 2016, entiende que los hechos revisten inicialmente los carácteres de los delitos tipificados en los arts. 578 y $510 \mathrm{CP}$, de los que serían autores los dos acusados. De este modo, señala que «obviamente, concurren los presupuestos exigidos por el Tribunal Supremo, para llegar a la conclusión de que efectivamente los hechos, a tenor de los cuales se produce la exhibición de un cartel, con la leyenda "Gora Alka-ETA», constituyen un delito de Terrorismo, pues tal hecho, supone enaltecer o justificar, públicamente los delitos terroristas cometidos no sólo por la Organización Terrorista ETA, sino también por AL-QAEDA, pues [...] la expresión Alka es un «juego de palabras», referido a la Organización terrorista antes citada, por lo 
Finalmente, el Auto del Juzgado Central de Instrucción n. ${ }^{\circ} 2$ de la Audiencia Nacional, de 28 de junio de 2016, acordó el sobreseimiento provisional de la causa abierta por el delito de ensalzamiento del terrorismo, remitiendo las actuaciones al Juzgado de Instrucción n. ${ }^{\circ} 46$ de Madrid, que conocería del delito tipificado en el art. $510.2 \mathrm{CP}^{68}$. En dicho auto, el Juzgado Central de Instrucción considera que pese a que los hechos tendrían objetivamente encaje en el delito de exaltación del terrorismo, no queda acreditado que la actuación de estos titiriteros estuviese dirigida a enaltecer o justificar la actividad terrorista o humillar a sus víctimas o sus familiares ${ }^{69}$.

La SAN 4/2017, de 21 de febrero (MP: C. Espejel Jorquera), conoció del polémico caso de José Miguel Arenas Beltrán, cuyo nombre artístico es Valtònyc, quien fue condenado por la comisión de un delito de enaltecimiento del terrorismo y de humillación de sus víctimas a raíz de una serie de canciones de rap publicadas en varios de sus discos, cantadas en sus recitales y difundidas en Internet durante los años 2012 y $2013^{70}$. La Audiencia Nacional entiende que sus letras, que poseen una particular

que la traducción del contenido de la pancarta o cartel exhibidos viene a significar »VIVA AL-QAEDA-ETA»» (FJ 2. ${ }^{\circ}$ ). Asimismo, el auto destaca que entre los efectos intervenidos a los acusados, que eran los exhibidos en su representación teatral, se encuentra una especie de cuaderno-libreto realizado a mano, en el que figura la portada del libro «Contra la democracia» de los Grupos Anarquistas Coordinados (GAC). El auto concluye que en este caso existe el riesgo real de que los dos titiriteros puedan volver a delinquir, oculten, alteren o destruyan fuentes de prueba relevantes para su enjuiciamiento, o intenten darse a la fuga. Respecto de la posible destrucción de los medios de prueba, PorTILla CONTRERAS se pregunta «¿A qué medios de prueba se refiere? ¿Los títeres?, ¿el cuaderno en blanco «Contra la democracia»?»; PORTILLA CONTRERAS, G., «El retorno de la censura...», cit., p. 88 .

68 El Auto del Juzgado de Instrucción n. ${ }^{\circ} 46$ de Madrid, de 5 de enero de 2017, estimó que tampoco había quedado debidamente justificada la perpetración del delito del art. $510.2 \mathrm{CP}$, por lo que decretó el sobreseimiento provisional de las actuaciones.

69 El referido auto expresa que «no queda suficientemente acreditado que tal hecho reúna todos los requisitos necesarios para llegar a estimar debidamente justificada la perpetración del delito antes referido, habida cuenta del resultado de todas las diligencias practicadas en el procedimiento, pues los actos de «enaltecimiento o justificación» además de tener que estar dotados de una publicidad de cierta calidad y capacidad de incidencia es necesario que se inscriban en una línea clara de concreto apoyo a acciones específicas de carácter terrorista en sentido estricto, lo que no ha quedado debidamente justificado en el presente caso, pues no consta suficientemente acreditado el elemento intencional doloso- de elogiar, enaltecer, alabar o justificar la actividad terrorista o menospreciar o humillar a las víctimas de delitos terroristas o sus familiares» (FJ 2. ${ }^{\circ}$ ).

70 En las letras de sus canciones podemos encontrar, entre otras, las siguientes expresiones: "Un pistoletazo en la frente de tu jefe está justificado o siempre queda esperar a que le secuestre algún GRAPO», "Dicen que pronto se traspasa la cloaca de Ortega Lara y muchos rumorean que Rubalcaba merece probarla, complejo de zulo mi casa a ver si un día secuestro alguno y le torturo mientras le leo al Argala", "Queremos que el miedo llame a sus puertas con llamas", "O que explote un bus del PP con nitroglicerina cargada", "Un día coches volarán como Carrero Blanco y no colgaremos ningún lazo en el Ayuntamiento", "Mataría a Esperanza Aguirre, pero antes, le haría ver como su hijo vive entre ratas», "Cogeré un kalashnikov, una MP5, iré a Intereconomía, terminaré con este circo», "Después mutilaré 
agresividad y dureza ${ }^{71}$, no se encuentran amparadas por las libertades de expresión y de creación artística invocadas por el acusado y se basa en que el caso examinado es sustancialmente coincidente con el resuelto en la STS 4/2017, de 18 enero (caso Strawberry), en la que se hizo hincapié en que resulta indiferente que el acusado no busque realizar una defensa o justificación de los actos violentos desarrollados por una organización terrorista y que tampoco pretenda lastimar el honor de sus víctimas o de sus familiares ${ }^{72}$.

Su recurso de casación fue resuelto por la STS 79/2018, de 15 de febrero (MP: F. Monterde Ferrer), la cual se adhiere completamente a las argumentaciones aducidas por la sentencia de instancia y sostiene que las letras de sus canciones tienen un indudable carácter laudatorio de ETA y GRAPO, sin que se trate de una mera exteriorización de su ideología, sino de una clara defensa de los medios violentos empleados por aquellas organizaciones terroristas, con incitación a su reiteración. En este supuesto, ni la Audiencia Nacional ni el Tribunal Supremo otorgan relevancia alguna a la finalidad o motivación con la que actúa el autor al proferir aquellas expresiones ni al contexto de ausencia de violencia terrorista nacional en el que se producen los hechos.

Otro caso relacionado con el mundo de la música y que llamó la atención de los medios fue el del grupo de rap «La Insurgencia», cuyos miembros fueron acusados de enaltecimiento del terrorismo por el Ministerio Fiscal al estimar que el contenido de sus canciones, publicadas en YouTube entre los años 2014 a 2016, ensalzaba de una manera casi sistemática a la organización terrorista GRAPO, así como a sus integrantes, manteniendo una tónica subversiva frente al orden constitucional democrático ${ }^{73}$. Este caso fue resuelto por la SAN 34/2017, de 4 de di-

a la De Cospedal,con la rabia del pueblo Vasco a los GAL», "Matando a Carrero ETA estuvo genial, a la mierda la palabra, viva el amonal».

${ }_{71}$ Los magistrados consideran que las letras de sus canciones «tienen, de un lado, un indudable contenido laudatorio de las organizaciones terroristas ETA y GRAPO, de sus integrantes y de las acciones violentas desplegadas por los mismos, justificándolas e incitando incluso a su reiteración y comportan, de otro lado, un claro menosprecio y humillación de las víctimas del terrorismo» (FJ 1..$^{\circ}$ ).

72 Por la comisión de este delito le fueron impuestas las penas de dos años de prisión e inhabilitación absoluta durante ocho años. Además, fue condenado a la pena de un año de prisión por la comisión de un delito de calumnias e injurias graves a la Corona (art. $490.3 \mathrm{CP}$ ), así como a la pena de seis meses de prisión por un delito de amenazas no condicionales (art. 169.2 CP). Dichas amenazas fueron proferidas contra Jorge Campos Asensi, presidente de la Fundación Circulo Balear, quien ejerció la acusación particular en este procedimiento.

${ }^{73}$ Algunas de las estrofas de sus canciones son las siguientes: «mis héroes son GRAPO», "si quieres acabar con los fusiles hacen falta bolas, por eso no condeno la lucha armada", "incitar al desacato y si es necesario empuñar las armas como los GRAPO», "sois carne de Gestapo no es violencia, es autodefensa», "...atracaré bancos, los responsables saborearan la cal viva, sin es que no llegan tan arriba como Carrero Blanco", "legítimo como expropiar un Carrefour o entrar en la sede del PP sacar la pipa y (sonido de disparo)", "aquí se apoya 
ciembre (MP: M. T. Palacios Criado), la cual comenzó analizando si el rap, como forma musical, puede utilizarse para cometer este delito. Para otorgar una respuesta afirmativa a dicha cuestión, la Audiencia Nacional acude a la STC 112/2016, de 20 de junio (FJ 2. ${ }^{\circ}$ ), que se refiere a «todas las formas de expresión que propaguen, inciten...», lo que significa que han de incluirse las canciones como forma de incurrir en esta conducta delictiva ${ }^{74}$.

Pese a reconocer que los acusados se encontraban desconcertados y contrariados ante la idea de que sus canciones pudiesen incitar a la violencia terrorista, los magistrados no aceptaron el argumento proporcionado por estos músicos de que era en sentido metafórico como se pronunciaban musicalmente hablando y que no tenían intención de incitar o provocar la comisión de nuevos delitos de terrorismo. Más adelante, la Sala trae a colación la STS 378/2017, de 25 de mayo, así como el voto particular formulado por el magistrado Xiol Ríos a la STC 112/2016, de 20 de junio, que, como se ha explicado, tuvieron en cuenta en favor de los acusados que las conductas desplegadas por aquéllos se habían producido en un contexto de ausencia de violencia terrorista relacionado con ETA y GRAPO. No obstante, pese a que la Audiencia Nacional alude a lo expresado en aquellas sentencias y afirma que «en el presente caso, las publicaciones datan de entre los años 2014 a 2016, de modo que la más antigua es posterior a 2012 y por ende aun más alejado en el tiempo de la existencia de GRAPO»(FJ 5. ${ }^{\circ}$ ), no otorga relevancia alguna al mo-

la insurrección armada, el que no sea partidario se convierte en adversario", "hacen falta comandos que empuñen las pistolas», "también hacen falta muchos contenedores ardiendo».

${ }^{74}$ Aun estando de acuerdo en que una canción de rap no debe quedar fuera del ámbito del Derecho penal per se, sí que se debe tener en cuenta su especial configuración como creación artística, ya que, como advierte SÁEz VALCÁrCEL, los tribunales no deben aplicar los mismos criterios de análisis para examinar la relevancia penal de un artículo de opinión, un ensayo o una declaración oral, que de una obra de ficción o de creación artística. Véase, al respecto, SÁEZ VALCÁRCEL, R., "La libertad de expresión. Apariencia y realidad», en Boletín Límites a la libertad de expresión, Juezas y Jueces para la democracia, 2018, p. 4. A diferencia de lo que sucede en aquellos supuestos en los cuales las frases o expresiones controvertidas son transmitidas al público general a través de tuits o comentarios en Internet, desprovistos de un plus que ayude a darse cuenta de su verdadera intención o del sentido de su mensaje, es de general conocimiento - aun más por aquellas personas que escuchan ese género musical- que el rap utiliza un lenguaje transgresor y extremo para atraer, provocar e incluso en ocasiones con el objeto de irritar, ofender o llamar la atención. En este sentido, la SAN 34/2017, de 4 de diciembre (FJ 2. ${ }^{\circ}$ ), reconoce, en referencia al rap como singular construcción musical, que «con el empleo de las figuras retóricas, especialmente la metáfora, a fin de enfatizar una idea o sentimiento, el autor, hablante o creador, hace escape del sentido literal de la palabra o frase, o este da un sentido diferente al comúnmente utilizado»; y señala que incluso los acusados hacen referencia a acontecimientos que ni siquiera han ocurrido y en ocasiones llegan a contenidos musicales que encierran una contradicción. Sin embargo, los magistrados consideran que ello no resta importancia al mensaje de odio que encierran sus canciones, las cuales, a su parecer, suponen una absoluta y calculada orientación en incitación a la violencia. 
mento temporal en que fueron publicadas las canciones de este grupo de rap, posteriores incluso a los mensajes que la STS 378/2017, de 25 de mayo, consideró atípicos ${ }^{75}$.

Respecto de la acreditación de la necesaria situación de riesgo, la sentencia sostiene que sus canciones pueden influir en las decisiones de aquellos que sean jóvenes, no posean un conocimiento cabal de los acontecimientos terroristas o se encuentren en situaciones de desesperación por su precariedad económica, e indica que determinados ámbitos de la sociedad (en concreto, políticos y banqueros) pueden quedar en una posición débil por ser los identificados como objeto de ataques en sus letras. En aplicación de los dos primeros apartados del art. 578, la Audiencia Nacional acaba dictando una sentencia por la cual condena a cada uno de los doce miembros de «La Insurgencia» a las penas de dos años y un día de prisión, multa de dieciséis meses, e inhabilitación absoluta por un periodo de ocho años y un día ${ }^{76}$.

Por otra parte, el rapero y poeta Pablo Rivadulla Duró, conocido artísticamente como Pablo Hasél ${ }^{77}$, fue acusado de haber cometido este delito a través de ciertas publicaciones que realizó en su cuenta de Twitter entre los años 2015 y $2016^{78}$. A diferencia del resto de supuestos

75 Insistiendo aun más en esta cuestión, la SAN 34/2017, de 4 de diciembre (FJ 5. ${ }^{\circ}$ ), llega a reconocer que «tanto la organización terrorista GRAPO como ETA, aparte de prácticamente desmanteladas e inoperantes en los últimos años, no han desplegado actividad de esa índole a la fecha de los hechos, y sin que, tal como destacó algún acusado, se hayan reactivado con motivo de los contenidos alusivos a ambas en las canciones, lo que pudiera descartar cualquier rasgo de interferencia para el resurgir de una y otra organización terrorista a sus inherentes actividades de esa índole, alentadas por el proceder de los acusados». A pesar de admitir aquéllo, advierte que el riesgo ha de entenderse en abstracto, por lo que entiende que aquel contexto no provoca la atipicidad de los hechos.

${ }_{76}$ Esta sentencia cuenta con un voto particular de la magistrada M. ${ }^{a}$ Ángela Murillo Bordallo, que discrepó de la condena impuesta y vino a decir que se trataba de un grupo de jóvenes que simplemente querían abrirse paso en el mundo de la música escribiendo y publicando canciones provodoras, acordes con sus ideales y pensamientos políticos, cuyo auténtico fin era lograr notoriedad y reputación en el mundo del «hip-hop», no incitar al resurgimiento de la violencia terrorista nacional.

77 Pablo Hasél tenía antecedentes penales como autor de un delito de enaltecimiento del terrorismo, puesto que había sido condenado por la SAN 8/2014, de 31 de marzo (MP: A. Díaz Delgado), por la comisión de dicho delito a las penas de dos años de prisión y doce años de inhabilitación absoluta, al haber publicado en Youtube, entre los años 2009 y 2011, diversos videos en los que ensalzaba el terrorismo. Su condena fue confirmada por la STS 106/2015, de 19 de febrero.

78 Asimismo, fue acusado de un delito de injurias y calumnias contra la Corona y utilización de la imagen del Rey (art. 491.1 y 2 CP) y de un delito de injurias y calumnias contra las Instituciones del Estado (art. 504.2 CP). Este caso se diferencia de los dos anteriores en que si bien se trata de un cantante de rap, los mensajes que la acusación pública consideró que enaltecían el terrorismo provenían exclusivamente de sus comentarios en Twitter, ya que la canción que se enjuició constituía presuntamente un delito de calumnias e injurias contra la Corona. Algunos de los tuits que la Audiencia Nacional estimó que incurrían en un delito de enaltecimiento del terrorismo son los 
comentados, este procedimiento judicial comenzó a raíz de una denuncia formulada por un ciudadano que puso en conocimiento de la Fiscalía las publicaciones de este rapero ante la sospecha de que pudiesen constituir un delito. La SAN 3/2018, de 2 de marzo (MP: N. Poveda Peñas), que conoció de este procedimiento, centró su atención fundamentalmente en la frase «las manifestaciones son necesarias, pero no suficientes, apoyemos a quienes han ido más allá», que escribió el acusado junto a una foto de Victoria Gómez Méndez, miembro histórico del grupo terrorista GRAPO. Los magistrados estimaron que de dicho comentario se advertía una llamada a la audiencia a apoyar a los que van «más allá» de las manifestaciones y pese a que el acusado no había dado explicaciones sobre que significaban aquellas palabras, la Sala entendió que, en simple lógica, ello equivalía a instar a quienes leyesen sus mensajes a que abandonasen la protesta pacífica, convirtiéndola en una protesta violenta ${ }^{79}$.

La Audiencia Nacional sostiene que la actuación del acusado implica un riesgo abstracto de que se produzcan nuevos actos terroristas, ya que sus mensajes contemplan un llamamiento a la violencia en la confrontación con las Instituciones y los Cuerpos y Fuerzas de Seguridad del Estado. Además, destaca que sus tuits han tenido un efectivo impacto en la opinión pública. Los magistrados consideran que el hecho de que un particular denunciase los comentarios publicados por Pablo Hasél por considerar que eran delictivos constituye un factor determinante de que su conducta ha creado un riesgo real para la seguridad colectiva de los ciudadanos ${ }^{80}$. La Sala entiende que, dada la condición que tiene el acusado como intérprete de rap, posee una mayor capacidad de que sus mensajes lleguen a un gran número de personas ${ }^{81}$.

siguientes: "Ante el terrorismo de Estado del Barrio organizado", "Las manifestaciones son necesarias, pero no suficientes, apoyemos a quienes han ido más allá", "Mónica y Francisco, 12 años de prisión por daños materiales en una basílica Guardia Civil impunidad por decenas de emigrantes asesinados", "2 años desde que Isabel Aparicio fue exterminada por comunista, negándole el Estado la asistencia médica en prisión», "Juan Martin Luna militante del PCE ( $r$ ) asesinado por la policía por defender nuestros derechos».

79 De este modo, la sentencia indica que «se trata de un mensaje que encierra claramente una invitación a realizar una conducta igual que la de "sus referentes», se incita a tratar de emular sus actos, en definitiva, actividad violenta y terrorista que representa una forma de lucha encomiable y positiva según su criterio, en definitiva una exaltación de la violencia que pretende solapar bajo forma de opinión, incluso con peligro para el orden constitucional y la paz social y las personas» (FJ $\left.1 .^{\circ}\right)$.

80 De este modo, la sentencia expresa que sus mensajes "han tenido impacto en la opinión pública, ya que no debemos olvidar que el origen de la actividad instructora proviene de un mensaje remitido con carácter de denuncia a la Fiscalía por particular alarmado por la aparición de dichos tuits en tal medida como para realizar una denuncia indicando su nombre y perfil» (FJ 3. ${ }^{\circ}$ ).

81 Asimismo, los magistrados aluden a sus antecedentes penales y a la concreta frase a la que se ha hecho mención para contribuir a probar dicho riesgo, indicando que su comportamiento no se circunscribe a un mensaje concreto o una conducta ocasional, sino que «obedecen a una trayectoria continuada del acusado en su actuación que en su día generó una condena por este mismo tipo penal y que junto con los otros tuits examinados, 
Llama la atención que se utilice el dato de la denuncia efectuada por aquel ciudadano para inferir que la conducta desplegada por el acusado ha tenido un impacto en la opinión pública y, por ende, ha generado un riesgo para la sociedad. De acuerdo a los datos proporcionados por la propia sentencia, en el momento de difundirse aquellos mensajes, Pablo Hasél tenía más de 54.000 seguidores en su cuenta de Twitter y había publicado 1.915 tuits de similar temática que los que fueron enjuiciados. A esas más de cincuenta mil personas, habría que sumar todos aquellos ciudadanos que probablemente visitaron su perfil durante esos años, pues hemos de recordar que en algunos perfiles, como el del acusado, no hace falta ser un seguidor para poder visualizar sus contenidos. En definitiva, aunque no sea posible calcular el número exacto, de las miles de personas que vieron aquellos mensajes, tan solo una de ellas decidió presentar una denuncia por sentirse alarmado ante su contenido. Es evidente que un solo ciudadano no puede constituir la opinión pública.

No obstante, la Audiencia Nacional estimó que el acusado había cometido el delito de enaltecimiento del terrorismo que se le imputaba y, aplicando también en este caso los dos primeros apartados del art. 578 $\mathrm{CP}$, así como la circunstancia agravante de reincidencia del art. 22.8. ${ }^{\mathrm{a}}$ $\mathrm{CP}$, le impuso las penas de dos años y un día de prisión, multa de quince meses, inhabilitación absoluta e inhabilitación especial para profesión u oficio educativos en los ámbitos docente, deportivo y de tiempo libre por un periodo de ocho años y un día ${ }^{82 / 83}$.

forman un conjunto de actuación generador de dicho riesgo, aun cuando no sea concreto, sino en abstracto, ya que el propio acusado al contestar a las preguntas del Ministerio Fiscal en el acto del juicio, no supo concretar la frase más allá, dando a entender una indeterminación, que como el Tribunal considera amparaba cualquier tipo de actividad «más allá» de la actividad pacífica de las manifestaciones, la que establece como no suficiente, debiendo acudirse a la vía violenta, ya que no existe otra explicación lógica a sus palabras» (FJ 3. ${ }^{\circ}$ ). La Audiencia Nacional deduce que la única explicación posible es que el acusado estuviese intentando animar, incitar, a que sus seguidores emulasen los actos violentos llevados a cabo por los miembros de la organización terrorista GRAPO.

82 La sentencia también dictaminó que Pablo Hasél había cometido los delitos de injurias y calumnias contra la Corona y de injurias y calumnias contra las Instituciones del Estado, imponiéndole las penas de multa de doce y quince meses, respectivamente.

83 Como viene siendo habitual en esta materia, la decisión condenatoria del Tribunal no fue unánime, sino que la magistrada Manuela Fernández Prado formuló un voto particular a esta sentencia en el que defendió que Pablo Hasél debería haber sido absuelto de los tres delitos por los que había sido acusado. Centrándonos en el ensalzamiento del terrorismo, la magistrada comienza compartiendo la crítica antes expuesta de que no puede concluirse que el hecho de que haya existido la denuncia de un ciudadano es un dato que pruebe que se ha creado una situación de riesgo para la paz pública o el orden constitucional. En este sentido, afirma que «la sentencia del TS de 31.01.2018 recoge como en la sentencia recurrida ya se indicaba que la mejor demostración de la ausencia de riesgo estaba en que los tuits sólo fueron detectados cuando los investigadores realizaron una prospección en la red social. Pero de este razonamiento no puede sacarse la conclusión de que, si existe la denuncia de un ciudadano, es que ha existido riesgo, como en definitiva pretende la resolución de la mayoría». Acto seguido, Fernández Prado 


\section{La atenuación de las penas en aplicación del art. 579 bis.4 CP.}

El segundo apartado del art. $578 \mathrm{CP}$, introducido en la reforma operada por la LO 2/2015, de 30 de marzo, dispone lo siguiente: «Las penas previstas en el apartado anterior se impondrán en su mitad superior cuando los hechos se hubieran llevado a cabo mediante la difusión de servicios o contenidos accesibles al público a través de medios de comunicación, Internet, o por medio de servicios de comunicaciones electrónicas o mediante el uso de tecnologías de la información» ${ }^{84}$. En este caso, se tiene en cuenta que a través de estas vías los mensajes de ensalzamiento del terrorismo o de humillación de sus víctimas pueden llegar a un gran número de personas de forma instantánea y perdurar en el tiempo, produciéndose un riesgo cada vez mayor de que el terrorismo encuentre un fuerte apoyo y de que el ataque al honor y dignidad de sus víctimas sea más intenso y duradero.

Sin embargo, lo cierto es que en la práctica este apartado, que debía constituir una agravación del tipo básico, ha terminado por convertirse en el tipo genérico de este delito, ya que la gran mayoría de casos de ensalzamiento del terrorismo que llegan a nuestros tribunales son detectados a través de Internet y, en concreto, de las redes sociales. En este sentido, Correcher Mira advierte que eel tratamiento jurídico-penal de este delito supondría llegar a una situación tal de absurdo que para reconocer los elementos objetivos del tipo genérico fuera necesario aplicar la modalidad agravada del delito ${ }^{85}$. Como pone de manifiesto este

realiza un minucioso análisis de cada uno de los comentarios del acusado y concluye que ninguno de ellos implica un llamamiento unívoco a la violencia y no parece que puedan ser susceptibles de generar una situación de riesgo para persona alguna, por lo que no pueden considerarse constitutivos del delito de enaltecimiento del terrorismo. Respecto de la frase que resultó más controvertida, consistente en apoyar a quienes han ido "más allá» de las protestas pacíficas, la magistrada estimó que «este mensaje no tiene una interpretación clara, tampoco el acusado supo explicar, a preguntas del Ministerio Fiscal, a que se refería, precisamente por esa falta de claridad no podemos interpretarlo como un llamamiento público a la violencia».

84 Por su parte, el apartado tercero del art. 578 CP señala que «cuando los hechos, a la vista de sus circunstancias, resulten idóneos para alterar gravemente la paz pública o crear un grave sentimiento de inseguridad o temor a la sociedad o parte de ella se impondrá la pena en su mitad superior, que podrá elevarse hasta la superior en grado». Los apartados cuarto y quinto de dicho artículo recogen una serie de medidas que pueden acordar los jueces y tribunales con el fin de eliminar o retirar aquellos medios o soportes utilizados para la comisión de este delito, con el fin de evitar la rápida propagación o difusión del mensaje a través de Internet, de las tecnologías de la información y de los servicios de comunicaciones electrónicas.

85 CORRECHER MIRA, J., «El delito de enaltecimiento del terrorismo y humillación a las víctimas tras la reforma de la LO 2/2015 en materia de delitos de terrorismo", en Revista General de Derecho Penal, n. ${ }^{\circ}$ 27, 2017, p. 6. Consideración crítica que también realiza este autor en CORRECHER MIRA, J., «Límites penales a la libertad de expresión: 
autor, esta agravación obligatoria conlleva que la pena de prisión que se impondrá por la comisión de este delito será de dos años y un día a tres años, lo que veda la posibilidad de que el condenado pueda solicitar la suspensión de la ejecución de su pena de prisión de conformidad con lo dispuesto en el art. $80 \mathrm{CP}$, que prevé como una de las condiciones necesarias para dejar en suspenso su ejecución, que la pena o la suma de las impuestas no sea superior a dos años. Esto sucede incluso aunque el condenado carezca de antecedentes penales ${ }^{86}$.

A nuestro parecer, una de las principales razones de que los procedimientos judiciales que se han ido sucediendo por enaltecimiento del terrorismo hayan llamado de forma tan notable la atención de los medios de comunicación es que estas conductas se han castigado con penas de prisión. Probablemente, el resultado mediático no hubiese sido el mismo si el art. 578 previese alternativamente la pena de prisión o de multa como consecuencias penológicas de la comisión de este delito, pues los tribunales podrían haber optado por una u otra en función de la gravedad de los hechos. Sin embargo, su tenor literal recoge conjuntamente ambas penas aplicables ${ }^{87}$.

Aun así, hasta hace poco tiempo aquellas penas privativas de libertad no conllevaban la entrada en prisión de los condenados, ya que, en la gran mayoría de casos, los hechos que habían dado lugar a su enjuiciamiento habían acontecido con carácter previo a la entrada en vigor de la reforma del Código Penal del año 2015, por lo que, en virtud de la irre-

sobre el enaltecimiento del terrorismo en redes sociales», en Cuadernos electrónicos de filosofía del derecho, n. ${ }^{\circ}$ 39, 2019, p. 329. En proporción, son pocos los procedimientos judiciales que no han tenido su origen en Internet, como ha sucedido, por ejemplo, con los actos de homenaje a miembros de ETA y GRAPO realizados en lugares públicos. Puede citarse, por ejemplo, la SAN 31/2006, de 27 de abril (MP: F. L. Sánchez Martínez), que impuso a Arnaldo Otegi una pena de quince meses de prisión y siete años y tres meses de inhabilitación absoluta por intervenir como orador en un homenaje a J.M. Beñarán, «Argala», uno de los máximos dirigentes de ETA, con motivo del $25 .^{\circ}$ aniversario de su asesinato. Esta resolución fue confirmada por la STS 585/2007, de 20 de junio (MP: S. F. García Pérez).

86 No han faltado críticas en nuestra doctrina a la agravación penológica prevista actualmente en el art. 578.2 CP. Véanse, especialmente, TERUEL LOZANO, G.M., "Internet, incitación al terrorismo y libertad de expresión en el marco europeo», en InDret, n. ${ }^{\circ}$ 3, 2018, pp. 25-26; BERNAL DEL CASTILLO, J., «El enaltecimiento del terrorismo...», cit., p. 27; y MIRA BENAVENT, J., «El delito de enaltecimiento...», cit., p. 312.

87 Miró LLINARES afirma que la interpretación que están haciendo los tribunales del delito de enaltecimiento del terrorismo y de humillación de sus víctimas lo configura como «un delito de ofensa, que criminaliza comportamientos no por su capacidad para lesionar de forma directa o remota la autonomía personal afectando a un interés personal o colectivo, sino por su carácter ofensivo y contrario a sentimientos colectivos». Por ello, este autor considera que «dado que el precepto establece tanto la pena de prisión como la multa, como sanciones aplicables a estas conductas, tal intervención penal sería legítima, siempre que cuando lo que se estuviera sancionando fuera una ofensa se optara por aplicar la pena de multa». Véase, al respecto, MIRÓ LLINARES, F., «Derecho penal y 140 caracteres...», cit., pp. 42 y ss. 
troactividad de las disposiciones penales desfavorables, no les resultaba aplicable la agravación prevista en el art. 578.2 CP. No obstante, hemos visto que aquella suerte no la han tenido Pablo Hasél ni el grupo de rap "La Insurgencia», que fueron condenados a las penas de dos años y un día de prisión por difundir sus mensajes y canciones a través de Internet $^{88}$.

Afortunadamente, la Sala de Apelación de la Audiencia Nacional ha comenzado a paliar en parte la evidente desproporción que aquellas penas de prisión conllevan acudiendo a la atenuación penológica prevista en el apartado cuarto del art. 579 bis CP, el cual dispone que «los jueces y tribunales, motivadamente, atendiendo a las circunstancias concretas, podrán imponer también la pena inferior en uno o dos grados a la señalada en este Capítulo para el delito de que se trate, cuando el hecho sea objetivamente de menor gravedad, atendidos el medio empleado o el resultado producido ${ }^{89}$. Se trata de un precepto que hasta este momento y con carácter general los tribunales se habían negado a aplicar en esta materia ${ }^{90}$.

La Sala de Apelación de la Audiencia Nacional, en su sentencia n. ${ }^{\circ}$ 4/2018, de 10 de julio (MP: Enrique López López), conoce del recurso de apelación interpuesto por el Ministerio Fiscal contra la sentencia de instancia ${ }^{91}$ que había absuelto a un sujeto acusado de enaltecer el terrorismo en sus publicaciones de Twitter entre los años 2012 a $2016^{92}$. La

88 No hacemos referencia al caso de Valtònyc, ya que si bien fue condenado a una pena de prisión total de tres años y seis meses por los tres delitos cometidos, respecto del delito de enaltecimiento del terrorismo y de humillación de sus víctimas se le impuso una pena de prisión de dos años, puesto que sus canciones fueron difundidas entre los años 2012 y 2013, siendo, por tanto, anteriores a la reforma del Código Penal de 2015.

89 Respecto del ámbito de aplicación de dicho precepto, véase el Acuerdo del Pleno No Jurisdiccional de la Sala Segunda del Tribunal Supremo, de 24 de noviembre de 2016.

90 Así, por ejemplo, la SAN 9/2017, de 29 de marzo, que condenó a la tuitera Cassandra Vera, rechazó aplicar el art. 579 bis.4 CP para atenuar la pena con base en que «el delito fue cometido en el largo periodo de tres años y [...] no se observa en el acusado ninguna muestra de aflicción por el resultado producido». Por su parte, la STS 4/2017, de 18 de enero, estimó que no debía aplicarse dicho artículo y rebajar la pena impuesta a César Strawberry debido a que «el hecho de que se trate de unos mensajes difundidos a partir de una cuenta de Twitter con más de 8.000 seguidores, cada uno de ellos potenciales redireccionantes de tales mensajes, descarta la calificación de los hechos como de menor gravedad».

91 El Ministerio Fiscal puso interponer su recurso de apelación ante la Sala de Apelación de la Audiencia Nacional, sin tener que acudir directamente al Tribunal Supremo a través de un recurso de casación, debido a que Ley 41/2015, de 5 de octubre, de modificación de la Ley de Enjuiciamiento Criminal para la agilización de la justicia penal y el fortalecimiento de las garantías procesales, modificó el art. 846 ter de la Ley de Enjuiciamiento Criminal e introdujo la posibilidad de interponer recurso de apelación ante la Sala de Apelación de la Audiencia Nacional contra las sentencias dictadas en primera instancia por la Sala de lo Penal de dicho tribunal.

92 Este sujeto había publicado, entre otros, los siguientes mensajes: "Soy del GRAPO puta España», "Colgaremos al último político con las tripas del último policía», "De siempre 
Sala de Apelación estima su recurso condenando al acusado al entender que su conducta era plenamente subsumible en el tipo penal del art. 578 $\mathrm{CP}^{93}$. No obstante, los magistrados deciden apreciar la atenuación recogida en el apartado cuarto del art. 579 bis CP con base en el reducido número de seguidores que el acusado tenía en su cuenta de Twitter (en torno a 250) y la escasa interactividad producida por los mismos. Se rebaja la pena de prisión en dos grados y se impone una pena definitiva de tres meses de prisión, así como una pena de inhabilitación absoluta de seis años y tres meses ${ }^{94}$.

La SAN 5/2018, de 14 de septiembre (MP: E. Velasco Núñez), resuelve el recurso de apelación interpuesto por la representación procesal de $\mathrm{Pa}$ blo Hasél contra la SAN 3/2018, de 2 de marzo. Esta sentencia recuerda que los actos terroristas objeto de elogio en sus publicaciones fueron realizados en un entorno de entre cinco y veinte años antes. Asimismo, destaca que en España se han producido un sin fin de actos terroristas de naturaleza muy diversa y que, en concreto, el último gran atentado mortal ha ocurrido en Cataluña, en agosto de 2017, costando la vida a quince personas ${ }^{95}$. No obstante, a diferencia de la sentencia de instancia,

antiespañol solo mira mis letras, anticonstitucional yo como la ETA!», "Borroka da bide bajarra (la lucha es el único camino)», "El terrorismo hoy por hoy parece ser la única opción pa que puedan entender que Canarias no se vende, lucha por defender».

93 Los magistrados afirman que las manifestaciones del acusado «van más allá de la expresión de coincidencia de objetivos políticos o expresión de vínculos ideológicos, siendo sin lugar a dudas una justificación de los medios violentos y una invitación a la utilización de métodos terroristas, representado el terrorismo como merecedor de elogio y el asesinato de policías y banqueros como algo necesario. Se destaca que tales expresiones son reiteradas en el tiempo y se publicaron por el acusado en una red social de acceso público y sin ningún tipo de restricción. También entendemos que está acreditada la intención de provocar o incitar como elemento tendencial, y en este sentido hay que tener en cuenta, no solo la literalidad explicita de algunos de los mensajes, sino y también, la prolongación en el tiempo de los mismos» (FJ 4. ${ }^{\circ}$.

94 Esta resolución judicial ha sido confirmada por la STS 185/2019, de 2 de abril (MP: S. Polo García).

${ }_{95}$ Ante las alegaciones planteadas por la defensa de Pablo Hasél de que sus mensajes no habían creado riesgo alguno para la seguridad ciudadana, la Sala de Apelación comparte el parecer de la sentencia de instancia y estima que sus publicaciones eran aptas para generar un riesgo cierto de inculcar entre sus múltiples seguidores en las redes sociales que se vea como positivo cierto tipo de terrorismo y de que alguno de ellos, ante la banalización del ataque a ciertos colectivos (Corona, Cuerpos y Fuerzas de Seguridad del Estado, etc.), acabe usando la violencia como manera justificada de actuación. Los magistrados ponen de manifiesto que «se constata que se enalteció la trayectoria delictiva de varias personas exclusivamente en razón a su involucración en execrables delitos terroristas, [...] y que la intención al hacerlo de forma reiterada y pública, en redes sociales con miles de seguidores, por persona ya condenada por lo mismo en el pasado, fue intentar que alguno de sus lectores asumiera el discurso del odio que así propagaba para ver si reanudaba la acción violenta terrorista con alguno de los fines que el Art. 573 CP señala, que justificaba, poniendo en riesgo, a la mayoría pacífica de la población, de sufrir de nuevo el azote de facciones terroristas en fase de superación» (FJ $\left.4 .^{\circ}\right)$. Se vuelve a fundamentar el castigo penal en el hecho de que el procedimiento judicial se 
la Sala de Apelación se plantea si existen causas que deban atenuar la responsabilidad penal del recurrente y dictamina de forma afirmativa que debe aplicarse el referido art. 579 bis.4 CP para rebajar en dos grados las penas que le habían sido impuestas. Para ello, tiene en cuenta que las organizaciones criminales que protagonizaron el terrorismo nacional llevan un tiempo importante sin realizar acciones terroristas, por lo que se ve muy reducida la posibilidad de que las mismas resurjan o vuelvan a cometer atentados a consecuencia de los mensajes de este músico.

Además, la Sala estima que las expresiones difundidas por aquél poseen una menor dureza que aquellas otras por las que fue condenado anteriormente y tiene en cuenta que algunas de ellas son anteriores a la reforma del año $2015^{96}$. Aunque los magistrados afirman que estas circunstancias no son suficientes para absolver al recurrente, atendiendo a la proporcionalidad de la sanción, consideran que las penas deben rebajarse en dos grados, modificando el fallo de la sentencia de instancia e imponiendo finalmente a Pablo Hasél, por el delito de enaltecimiento del terrorismo, la pena de prisión de nueve meses y un día y de multa de 168 días.

Por su parte, la SAN 6/2018, de 18 de septiembre (MP: E. López López), conoce en segunda instancia del caso de los miembros de «La Insurgencia» $\mathrm{y}$, al igual que la anterior sentencia, subraya que no debemos olvidar que en nuestro país se han perpetrado durante muchos años un gran número de actos de violencia terrorista protagonizados principalmente por ETA y GRAPO y muy recientemente por grupos yihadistas ${ }^{97}$.

hubiese iniciado por una denuncia de un ciudadano, en que no se trataba de un mensaje ocasional, sino de una trayectoria continuada, y en el llamamiento que había realizado el recurrente a ir "más allá» de las protestas pacíficas.

96 De este modo, la SAN 5/2018, de 14 de septiembre (FJ 4. ${ }^{\circ}$ ), toma en consideración las siguientes circunstancias: «a) la organización terrorista a cuyos fines sirvió la acción de determinados integrantes cuya actividad violenta fue enaltecida por el acusado lleve un tiempo importante sin realizar acciones terroristas, la posibilidad de puesta en peligro de que la misma se reavive por obra de la influencia del recurrente en consecuencia, será menor, así como al hecho de que b) objetivamente las expresiones incitantes en Internet emitidas en esta ocasión por el acusado estén más comedidas y son menos explícitas que aquellas por las que se le condenó en un pasado y c) algunos tuits fueron exteriorizados con anterioridad a la entrada en vigor de la reforma sobre terrorismo operada en el Código Penal en 2015, aunque el resto no, entendemos que se erigen en circunstancias que, sin vaciar el contenido del tipo penal, deben tenerse en consideración a la hora de fijar, en favor del acusado, la mínima pena legal en concreto».

97 La Sala de Apelación señala que basta con leer los hechos probados para comprender la gravedad de las expresiones contenidas y su encaje en el tipo penal, al concurrir cuantos elementos adicionales o complementarios exige la jurisprudencia. Así, los magistrados entienden que existe «un riesgo indirecto de incitación a la comisión de actos violentos de carácter terrorista debido al elevado número de contenidos audiovisuales, a su reiteración, al homenaje laudatorio, como «ejemplos a seguir», de numerosos terroristas, 21 miembros identificados del PCR(r)-GRAPO y, en definitiva, a la consideración de que la violencia es una forma de defender los derechos políticos. Tales manifestaciones van más allá de la expresión de coincidencia de objetivos políticos 
Sin embargo, la Sala de Apelación estima que en este supuesto también debe aplicarse el apartado cuarto del art. 579 bis CP para atenuar las penas impuestas a los recurrentes al considerar que a pesar de la literalidad y la peligrosidad intrínseca de sus expresiones, ha de tenerse en cuenta que tanto la organización terrorista GRAPO como ETA, aparte de prácticamente desmanteladas e inoperantes en los últimos años, no han desplegado actividad armada a la fecha de los hechos, ni en la actualidad. Aun así, advierte que un gran número de delitos cometidos por aquellos grupos terroristas todavía están pendientes de esclarecimiento y que la multitud de personas que fueron víctimas de sus atentados aun deben soportar el sufrimiento que les ha supuesto para sus vidas y las de sus familiares.

Es decir, la sentencia estima que el desvalor de la acción no desaparece por el hecho de que estas organizaciones terroristas no hayan ejercido la violencia durante estos últimos años, pero sí que se ve reducido, ya que el riesgo abstracto que ocasiona la conducta de los recurrentes al ensalzar a este tipo de bandas terroristas que han sido prácticamente desmanteladas y cuya capacidad de actuación es escasa, es menor que cuando se enaltece o justifica la actuación de organizaciones terroristas que están presentes en nuestra sociedad, como es el caso del terrorismo yihadista ${ }^{98}$. Al rebajar sus penas en dos grados, la Sala de Apelación im-

o expresión de vínculos ideológicos, siendo sin lugar a dudas una justificación de los medios violentos y una invitación a la utilización de métodos terroristas, representado el terrorismo como merecedor de elogio y el asesinato de policías y banqueros como algo necesario» (FJ 4..$^{\circ}$ ). Asimismo, el tribunal recalca que su intento de enmarcar sus expresiones musicales en un mero sentido metafórico de sus emociones y pensamientos, no resta un ápice al contenido altamente incitador que encierran, lo cual se ve reforzado con determinadas imágenes que acompañan a algunas de sus canciones y acentúan, aun más, tal incitación a la violencia. En consecuencia, la sentencia advierte que «el género musical por sí mismo no puede suponer suerte alguna de elemento negativo del tipo y por ello, si bien el lenguaje del rap es extremo, provocador, alegórico y simbólico, la alabanza, la justificación de los terroristas y sus acciones, aunque sea en este formato, no puede quedar fuera del ámbito del injusto del art. 578 del CP; es imposible disociar el género musical bajo la forma de rimas de su contenido, que como se ha visto, es claro y literosuficiente como para albergar tanto el elemento objetivo como el subjetivo del delito» (FJ 4..$^{\circ}$. Concluye, pues, que las letras de sus canciones son aptas para incrementar de forma mínima, que es suficiente, el peligro de comisión de delitos terroristas.

98 En este sentido, el tribunal destaca que «si bien es cierto que, en el presente momento, ese padecimiento y miedo se han visto ostensiblemente reducidos, no puede de ninguna forma olvidarse que tal organización terrorista no se ha disuelto y que una parte considerable de sus delitos aun están pendientes de esclarecimiento, a la vez que se alude al sufrimiento de las innumerables víctimas y de sus familiares, a quienes no sólo el Estado y la ley debe amparar y reconocer, sino procurar su respeto y bienestar. Mas entendemos que [...] el desvalor de la acción cuando se alude a este tipo de bandas terroristas que han sido, como se ha dicho prácticamente desmanteladas, y que su capacidad de actuación es mínima, es menor que cuando se justifica o sublima la actuación de actividades terroristas que están presentes en nuestra sociedad, como es el caso del yihadismo, que ha causado la muerte de quince personas no hace más de un año» (FJ 5. ${ }^{\circ}$ ). 
pone finalmente a los miembros de «La Insurgencia» las penas de seis meses y un día de prisión y multa de cuatro meses.

Hemos visto que en la SAN 4/2018, de 10 de julio, se rebaja la pena de prisión en dos grados en aplicación del art. 579 bis.4 CP y se impone una pena definitiva de tres meses de prisión, así como una pena de inhabilitación absoluta de seis años y tres meses ${ }^{99}$. En los casos de Pablo Hasél y «La Insurgencia» no se ha mencionado la pena de inhabilitación porque ni en su fundamentación jurídica ni en su fallo se hace referencia alguna a la cuestión de si la atenuación prevista en el apartado cuarto del referido artículo afecta a la extensión de la duración de dicha pena. En efecto, de la lectura del art. 579 bis.4 CP no se desprende con claridad si la atenuación que el mismo prevé es aplicable a las penas de inhabilitación recogidas en su apartado primero, ya que aquel precepto indica que se podrá imponer «la pena inferior en uno o dos grados a la señalada en este Capítulo para el delito de que se trate», pareciendo referirse a la pena o penas principales, de prisión y multa, recogidas en el precepto concreto de cada delito de terrorismo. A nuestro parecer, la interpretación correcta, más respetuosa con el principio de proporcionalidad, sería considerar que la atenuación prevista en el apartado cuarto del antedicho artículo repercute también, de forma directa, en la extensión de la duración de las penas de inhabilitación ${ }^{100}$. Sin embargo, los tribunales no lo interpretan así, ya que estiman que la referida atenuación no debe modificar el límite mínimo de la extensión de la duración de las penas de inhabilitación.

Por ello, además de que resulta criticable que este delito también sea castigado con penas de inhabilitación absoluta e inhabilitación espe-

99 El primer apartado del art. 579 bis CP dispone que «el responsable de los delitos previstos en este Capítulo, sin perjuicio de las penas que correspondan con arreglo a los artículos precedentes, será también castigado, atendiendo proporcionalmente a la gravedad del delito, el número de los cometidos y a las circunstancias que concurran en el delincuente, con las penas de inhabilitación absoluta, inhabilitación especial para profesión u oficio educativos, en los ámbitos docente, deportivo y de tiempo libre, por un tiempo superior entre seis y veinte años al de la duración de la pena de privación de libertad impuesta en su caso en la sentencia». Como señala Boldova PaSAmar, lo dispuesto en aquel precepto «convierte a todos los del indicado capítulo en delitos graves (art. 13.4), aun cuando en algunos de ellos la pena de prisión no excede de cinco años», como sucede precisamente con este delito, el cual, como hemos visto, está castigado con una pena de prisión de uno a tres años y multa de doce a dieciocho meses, por lo que, en principio, si no fuera por la antedicha previsión legal, sería considerado un delito menos grave (art. 13.2 $\mathrm{CP}$, en relación con el art. 33.3 CP). Véase BOLDOVA PASAMAR, M.A., "Consecuencias sancionadoras de la radicalización terrorista de los menores de edad y su adecuación al perfil de jóvenes infractores», en Terrorismo, Sistema Penal y Derechos Fundamentales, Alonso Rimo (dir.), Tirant lo Blanch, Valencia, 1. ${ }^{\text {a }}$ ed., 2018, p. 690.

100 Resultando aplicables, por ejemplo, en caso de apreciar una rebaja de dos grados, las penas de inhabilitación absoluta y especial por un tiempo superior entre un año y seis meses a tres años (menos un día) al de duración de la pena de prisión. 
cial $^{101}$, no podemos pasar por alto la incongruencia que supone que aunque resulte probado en el procedimiento judicial que el acto de enaltecimiento o justificación del terrorismo reviste objetivamente una menor gravedad, deban aplicarse siempre dichas penas de inhabilitación con una duración mínima de seis años. No se trata de una cuestión baladí, ya que aunque las penas impuestas a Pablo Hasél y a los miembros de «La Insurgencia» fueron rebajadas en dos grados, aun así fueron castigados con unas penas de inhabilitación de seis años, nueve meses y un día, y seis años, seis meses y un día, respectivamente.

\section{Conclusiones.}

Aunque se ha examinado brevemente el tipo penal de humillación de las victimas, es innegable que este texto se ha centrado en la figura del enaltecimiento del terrorismo debido a su notable evolución jurisprudencial, especialmente intensa durante este último lustro. Así, hemos comprobado que durante más de una década ha imperado una interpretación estrictamente literal del primer inciso del art. $578 \mathrm{CP}$, sin que nuestros tribunales demandasen la presencia de un componente incitador a efectos de tipicidad ni la creación de un riesgo de comisión de futuros delitos de terrorismo. Criterio interpretativo que obviamente presentaba serios vicios de inconstitucionalidad por limitar en demasía el derecho fundamental a la libertad de expresión.

Afortunadamente, tras varias resoluciones del Tribunal Constitucional (ATC 4/2008, de 9 de enero, y STC 112/2016, de 20 de junio, siguiendo la postura interpretativa introducida por la STC 235/2007, de 7 de noviembre), se establece el criterio interpretativo de que solo puede punirse la conducta de ensalzamiento o justificación del terrorismo cuando constituya una incitación, aun indirecta, a la comisión de ulteriores delitos de terrorismo y se trate de una actuación que, desde una perspectiva ex ante, aumente el riesgo de que se perpetren tal clase de delitos, sin que sea necesario que lleguen a cometerse en el caso concreto ${ }^{102}$.

101 Pueden verse diversas críticas al art. 579 bis.1 CP (art. 579.2 CP con anterioridad a la reforma de 2015) en BERNAL DEL CASTILLO, J., "Observaciones en torno...», cit., pp. 1627 y ss.; GRUPO DE ESTUDIOS DE POLÍTICA CRIMINAL, Una alternativa a la actual politica criminal sobre terrorismo, Tirant lo Blanch, Valencia, 2008, p. 38; CAPITA REMEZAL, M., Análisis de la legislación..., cit., p. 184; MIRA BENAVENT, J., «El delito de enaltecimiento...», cit., p. 315; y PAREDES CASTAÑÓN, J.M., «Terrorismo y principio de intervención mínima: una propuesta de despenalización», en Terrorismo, Sistema Penal y Derechos Fundamentales, Alonso Rimo (dir.), Tirant lo Blanch, Valencia, 1. ' ed., 2018, p. 90.

102 En este sentido, la STS 378/2017, de 25 de mayo (FJ 2. ${ }^{\circ}$ ), recalca la importancia de «la valoración sobre el riesgo que se crea con el acto imputado. Por más que tal riesgo haya de entenderse en abstracto como «aptitud» ínsita en la actuación imputada, pero no referida a un concreto delito de terrorismo...». De este modo, el delito de enaltecimiento del 
Tampoco se requería inicialmente que concurriese en la actuación del autor una intención de provocar la comisión de delitos de terrorismo (entre otras, SsTS 90/2016, de 17 de febrero, 4/2017, de 18 de enero caso César Strawberry-, y 79/2018, de 15 de febrero —caso Valtònyc-). Sin embargo, la STS 378/2017, de 25 de mayo (seguida por las SsTS 560/2017, de 13 de julio, 600/2017, de 25 de julio, y 52/2018, de 31 de enero — caso Arkaitz Terrón-) advierte que el órgano judicial debe acreditar que la finalidad o intención del autor ha sido precisamente incitar o provocar, incluso de forma indirecta, la comisión de nuevos delitos de terrorismo, y que su comportamiento ha sido idóneo para originar la situación de riesgo, aunque dicho riesgo haya de entenderse en abstracto, no referido a un concreto delito de terrorismo.

A pesar de los avances jurisprudenciales que se han producido en esta materia $^{103}$, el delito de enaltecimiento del terrorismo continúa siendo objeto de severas críticas por parte de un sector de nuestra doctrina. En

terrorismo queda configurado como un delito de peligro hipotético o, en otra terminología, de aptitud abstracta (llamados también delitos de peligro posible o potencial), puesto que, desde un punto de vista objetivo, se exige «una acción apta o idónea para producir la lesión del bien jurídico protegido, donde lo característico es la posibilidad no la realidad del peligro para el objeto de tutela, con independencia de que éste haya entrado o no dentro del radio de acción del comportamiento antijurídico»; GÓMEZ TOMILLO, M., «Contribución a la teoría de los delitos de peligro hipotético-aptitud abstracta. Los delitos de tenencia como paradigma de peligro abstracto puro", en Estudios penales en Homenaje al Profesor Cobo del Rosal, Carbonell Mateu (coord.), Dykinson, Madrid, 1. a ed., 2005, p. 465. Se diferencia, por consiguiente, de los delitos de peligro abstracto puro, ya que, aunque en éstos tampoco pertenece al tipo la producción de un resultado de peligro, se caracterizan por la inexigencia de aptitud lesiva para el bien jurídico protegido. Es decir, respecto de estos últimos, no es necesario que se trate de una actividad que, ex ante, tenga la potencialidad suficiente para producir la lesión de aquel bien jurídico.

${ }_{103}$ Como hemos visto, aun no existe una jurisprudencia uniforme en la aplicación e interpretación de este delito. Ha resultado particularmente complicada para nuestros tribunales la valoración del contexto histórico y social en el que se difunde el mensaje, existiendo sentencias que no otorgan relevancia alguna al hecho de que la expresión controvertida se manifieste en un contexto de ausencia de violencia terrorista relacionado con aquellos grupos criminales a los que se elogia, como sucede con ETA y GRAPO (pueden citarse otra vez las SsTS 4/2017, de 18 de enero, y 79/2018, de 15 de febrero), resoluciones judiciales que sí tienen en cuenta este elemento contextual como un motivo esencial a la hora de absolver a los acusados (verbigracia, las SsTS 378/2017, de 25 de mayo, y 52/2018, de 31 de enero) y, últimamente, encontramos sentencias que, buscando una solución más moderada, condenan por este delito, pero atenúan las penas aplicables con base en dicho contexto al considerar que se minora el desvalor de la acción típica (SsAN 5/2018, de 14 de septiembre —caso Pablo Hasél, y 6/2018, de 18 de septiembre - caso «La Insurgencia»-). Al respecto, no podemos pasar por alto que los grupos criminales que protagonizaron el terrorismo nacional que asoló nuestro país durante muchos años ya no llevan a cabo actos de violencia terrorista y, al menos aparentemente, han desaparecido. Sin embargo, tampoco podemos olvidar que un gran número de los delitos que cometieron aun continúan sin resolverse. Además, es evidente que no puede afirmarse que se trate de hechos históricos, alejados de nuestro tiempo, puesto que los últimos atentados terroristas perpetrados por los miembros de aquellas organizaciones fueron realizados hace tan solo una década. Es decir, que cada postura respecto de la 
efecto, algunos autores estiman que los actos de exaltación o justificación del terrorismo deberían castigarse únicamente cuando impliquen una incitación directa a la comisión de ulteriores delitos terroristas, puesto que solo así se crearía un riesgo real e inminente para la paz pública o el orden constitucional 104. A nuestro parecer, solo podría alcanzarse un pleno respeto de nuestros principios penales básicos regresando al régimen de la apología establecido en nuestro Código Penal de 1995 con anterioridad a la entrada en vigor de la LO 7/2000, de 22 de diciembre, lo que supondría que solo se pudiesen castigar los actos de enaltecimiento o justificación del terrorismo que estuviesen expresa y directamente dirigidos a promover la comisión de un concreto y determinado delito de terrorismo, generando un riesgo real e inminente de que puedan perpetrarse tal clase de delitos 105.

trascendencia que ha de otorgarse en estos casos a la inexistencia de un contexto de violencia terrorista tiene sus pros y sus contras.

104 Como señala CuERDA ARnAu, la apología que es punible solamente como incitación directa a la comisión de un ulterior delito es la única «constitucionalmente intachable por ajustarse al conocido estándar del inminente y claro peligro»; CUERDA ARNAU, M.L., «Delitos contra el orden público», en Derecho Penal. Parte Especial, González Cussac

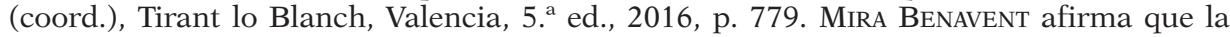
derogación de este delito «no comportaría ninguna laguna de punibilidad ni tampoco restaría eficacia en la prevención de los delitos de terrorismo, pues [...] los casos más graves y penalmente más peligrosos de enaltecimiento del terrorismo volverían a estar sometidos al régimen penal general de la apología establecido en el artículo 18 del Código penal y, por tanto, a los requisitos exigibles a cualquier provocación pública a cometer delito (es decir: creación de un peligro claro e inminente para los bienes jurídicos derivado del carácter directo y público de la incitación...»; MIRA BENAVENT, J., «El delito de enaltecimiento...», cit., p. 317. CARBonell Mateu considera se trata de «un delito contra los sentimientos, que pretende fundamentar el reproche penal en el rechazo moral ante afirmaciones que producen indignación, y profundo malestar social, pero que no suponen riesgo alguno para la perpetración de delitos de terrorismo»; CARBONELL MATEU, J.C., «Crítica a los sentimientos...», cit., p. 353. Por su parte, GaLÁN MuÑoz pone de manifiesto que «estamos, sin duda, ante una figura que castiga conductas muy alejadas de la efectiva y real puesta en peligro de los bienes jurídicos que trata de tutelar (vida, salud, etc...) y que, por tanto, presentan una muy escasa lesividad con respecto a dichos valores, lo que sitúa la legitimidad de la existencia de este delito en un terreno ciertamente pantanoso. Justo al borde de la producción de una limitación desproporcionada y, por tanto, ilegítima e inconstitucional de un derecho tan fundamental para los Estados democráticos como es el de la libertad de expresión»; GALÁN MUÑOZ, A., «El delito de enaltecimiento...», cit., p. 299.

105 Por consiguiente, acogeríamos la propuesta de reforma de este delito que ha realizado recientemente el GRUPo De Estudios de Política CRiminal, según la cual el art. 578.1 CP quedaría redactado de la siguiente forma: «La incitación pública y directa a la comisión de cualquiera de los delitos señalados en los artículos 572 a 577, la justificación o el enaltecimiento públicos de estos delitos o de sus autores, siempre que por su naturaleza y circunstancias constituyan una incitación directa a cometer uno de estos delitos, serán castigados con una pena de 1 a 3 años de privación de libertad cuando genere con ello un riesgo inminente de que se puedan cometer uno o varios de dichos delitos...». Véase GRUPO DE ESTUDIOS DE POLÍTICA CRIMINAL, Una propuesta alternativa de regulación de los delitos de expresión, Tirant lo Blanch, Valencia, 2019, pp. 46 y ss. 
Sin embargo, dado que la política criminal que se sigue actualmente en esta materia no es proclive a la supresión o modificación de este delito 106, la única solución que nos queda es demandar a nuestros tribunales su exclusiva aplicación a aquellos supuestos que presenten una extrema gravedad 107, realizando una interpretación restrictiva en la que se tenga en cuenta especialmente el contexto en el que se difunden los mensajes.

Asimismo, poniendo como ejemplo las citadas sentencias de la Sala de Apelación de la Audiencia Nacional, debemos solicitar una aplicación más generalizada de la atenuación prevista en el apartado cuarto del art. 579 bis CP. Estamos ante un delito de opinión que no debería castigarse con una pena de prisión, sino, en su caso, con una pena de multa. No obstante, ambas sanciones están previstas conjuntamente en el art. 578.1 $\mathrm{CP}$, por lo que es necesario que se reduzca drásticamente su duración acudiendo a la referida atenuación, paliando así, al menos en parte, la vulneración del principio de proporcionalidad que conlleva este delito.

Por último, reiteramos que la atenuación prevista en el apartado cuarto del art. 579 bis CP debería repercutir, de forma directa, en la extensión de la duración de las penas de inhabilitación recogidas en su apartado primero. De seguirse la interpretación de este precepto realizada en las mencionadas sentencias, se continuarán imponiendo penas de inhabilitación con una duración mínima de seis años aunque resulte acreditado en el procedimiento judicial que se trata de un acto de enaltecimiento o justificación del terrorismo que reviste objetivamente una menor gravedad.

\section{Bibliografía.}

Alonso Rimo, A., "Apología, enaltecimiento del terrorismo y principios penales», en Revista de Derecho Penal y Criminología, 3. a Época, n. ${ }^{\circ} 4$, 2010.

— «¿IMPUNIDAD GENERAL DE LOS ACTOS PREPARATORIOS? LA EXPANSIÓN DE LOS DELITOS DE PREPARACIÓN», EN INDRET: REVISTA PARA EL ANÁLISIS DEL DERECHO, N. ${ }^{\circ} 4,2017$.

Arias Castaño, A., "Amenazas, Enaltecimiento del Terrorismo y Libertad de Expresión: El caso De Juana Chaos», en Indret: Revista para el Análisis del Derecho, n. ${ }^{\circ}$ 4, 2007.

106 La Directiva 2017/541, de 15 de marzo, ha sido traspuesta recientemente a nuestro ordenamiento jurídico por la LO 1/2019, de 20 de febrero, sin que se haya realizado modificación alguna de los distintos apartados del art. 578 CP.

107 Entre los que no se encontrarían, a nuestro parecer, los referidos casos de los músicos Strawberry, Valtónyc, Pablo Hasél y los miembros del grupo «La Insurgencia». 
BERNAL DEL CASTILLO, J., «Observaciones en torno a la Ley Orgánica 7/2000 de 22 de diciembre, de modificación del Código penal en materia de terrorismo», en La Ley: Revista jurídica española de doctrina, jurisprudencia y bibliografía, n. ${ }^{\circ}$ 5, 2001.

— «El ENALTECIMIENTO DEL TERRORISMO Y LA HUMILLACIÓN A SUS VÍ́ctiMAS COMO FORMAS DEL «DISCURSO DEL ODIO»», EN REVISTA DE DERECHO PENAL Y CRIminología, 3. a Época, n. ${ }^{\circ}$ 16, 2016.

Boldova Pasamar, M.A., "Consecuencias sancionadoras de la radicalización terrorista de los menores de edad y su adecuación al perfil de jóvenes infractores», en Terrorismo, Sistema Penal y Derechos Fundamentales, Alonso Rimo (dir.), Tirant lo Blanch, Valencia, 1. ${ }^{a}$ ed., 2018.

CABELlos EsPiÉRREZ, M.A., «Opinar, enaltecer, humillar: Respuesta penal e interpretación constitucionalmente adecuada en el tiempo de las redes sociales», en Revista española de derecho constitucional, n. ${ }^{\circ} 112$, 2018.

CÁmara Arroyo, S., «Delitos de odio: concepto y crítica: clímite legítimo a la libertad de expresión?», en La Ley penal: revista de derecho penal procesal y penitenciario, n. ${ }^{\circ} 130,2018$.

Cancio Meliá, M., Los delitos de terrorismo: estructura típica e injusto, Reus, Madrid, 1. ${ }^{a}$ ed., 2010.

Cancio Meliá, M. / Díaz López, J. A., ¿Discurso de odio y/o discurso terrorista? Música, guiñoles y redes sociales frente al artículo 578 del Código Penal, Aranzadi, Navarra, 1. ${ }^{a}$ ed., 2019.

Capita Remezal, M., Análisis de la legislación penal antiterrorista, Colex, Madrid, 1. ${ }^{\mathrm{a}}$ ed., 2008.

Carbonell Mateu, J.C., «Crítica a los sentimientos como bien jurídicopenal: El enaltecimiento del terrorismo y la humillación a las víctimas "más allá de la provocación y la injuria»», en Terrorismo, Sistema Penal y Derechos Fundamentales, Alonso Rimo (dir.), Tirant lo Blanch, Valencia, 2018.

CAstellví Monserrat, C., «Terrorismo (arts. 571-580)», en Manual de Derecho Penal. Parte Especial. Doctrina y jurisprudencia con casos solucionados. Tomo 1, Corcoy Bidasolo (dir.), Tirant lo Blanch, Valencia, 2. ${ }^{\mathrm{a}}$ ed., 2015.

Cerezo Mir, J., Curso de Derecho Penal español. Parte General. II. Teoría jurídica del delito, Tecnos, Madrid, 6. ${ }^{\mathrm{a}}$ ed., 1998.

CORRECHER MIRA, J., "El delito de enaltecimiento del terrorismo y humillación a las víctimas tras la reforma de la LO 2/2015 en materia de delitos de terrorismo", en Revista General de Derecho Penal, n. ' 27, 2017.

— «LÍMITES PENALES A LA LIBERTAD DE EXPRESIÓN: SOBRE EL ENALTECIMIENTO DEL TERRORISMO EN REDES SOCIALES», EN CUADERNOS ELECTRÓNICOS DE FILOSOFÍA DEL DERECHO, N. ${ }^{\circ} 39,2019$. 
Cuerda Arnau, M.L., «Terrorismo y libertades políticas», en Teoría y derecho: revista de pensamiento jurídico, n. ${ }^{\circ}$ 3, 2008.

— «Delitos DE TERRORISMO: aSPECTOS SUSTANTIVOS Y PROCESALES», EN EL NUEVO PANORAMA DEL TERRORISMO EN ESPAÑA: PERSPECTIVA PENAL, PENITENCIARIA Y SOCIAL, JUANATEY DORADO (DIR.), Ed. Universidad de Alicante, $1 .^{\mathrm{a}}$ ed., 2013.

— «Delitos contra el orden público», en Derecho Penal. Parte Especial, González Cussac (coord.), Tirant lo Blanch, Valencia, 5. ${ }^{\text {a ed., }} 2016$.

Del Rosal Blasco, B., «La regulación legal de los actos preparatorios en el Código Penal de 1995», en Homenaje al profesor Dr. Gonzalo Rodríguez Mourullo, Jorge Barreiro (coord.), Civitas, 1. ${ }^{a}$ ed., 2005.

Dolz Lago, M.J., «Las actuaciones del Ministerio Fiscal en defensa de la dignidad de las Víctimas del Terrorismo, en El reconocimiento de las víctimas del terrorismo a través de la legislación y la jurisprudencia, Català i Bas (dir.), Cátedra de Derecho Autonómico Valenciano, Colección Cátedra Abierta n. ${ }^{\circ}$ 9, Valencia, 2013.

Fuster-Fabra ToRrellas, J.M., Responsabilidad civil derivada de los actos de terrorismo, Atelier, Barcelona, 1. ${ }^{a}$ ed., 2001.

Galán MuÑoz, A., «El delito de enaltecimiento terrorista. ¿Instrumento de lucha contra el peligroso discurso del odio terrorista o mecanismo represor de repudiables mensajes de raperos, twitteros y titiriteros?», en Estudios Penales y Criminológicos, vol. XXXVIII, 2018.

García Albero, R., «Título XXII. Delitos contra el orden público», en Comentarios al Código Penal Español. Tomo II (Artículos 234 a DF. 7. ${ }^{a}$ ), Quintero Olivares (dir.), Aranzadi, Navarra, 6. ${ }^{a}$ ed., 2011.

García De Blanco, V., «Delitos de terrorismo, cumplimiento de pena y separación de poderes: el caso «De Juana Chaos»», en Icade: Revista de las Facultades de Derecho y Ciencias Económicas y Empresariales, n. ${ }^{\circ} 72,2007$.

Gómez Navajas, J., «Sentencia de la Audiencia Nacional (Sala de lo Penal), de 15 de noviembre de 2016 [ROJ SAN 4038/2016]: absolución del delito de humillación de las víctimas del terrorismo», en Ars Iuris Salmanticensis: AIS: revista europea e iberoamericana de pensamiento y análisis de derecho, ciencia política y criminología, Vol. 5, n. ${ }^{\circ} 1,2017$.

Gómez Tomillo, M., «Contribución a la teoría de los delitos de peligro hipotético-aptitud abstracta. Los delitos de tenencia como paradigma de peligro abstracto puro», en Estudios penales en Homenaje al Profesor Cobo del Rosal, Carbonell Mateu (coord.), Dykinson, Madrid, 1. ${ }^{\mathrm{a}}$ ed., 2005.

Grupo De Estudios De Política Criminal, Una alternativa a la actual politica criminal sobre terrorismo, Tirant lo Blanch, Valencia, 2008. 
Grupo De Estudios De Política Criminal, Una propuesta de renovación de la política criminal sobre terrorismo, Tirant lo Blanch, Valencia, 2013.

- Una propuesta alternativa de regulación de los delitos de expresión, Tirant lo Blanch, Valencia, 2019.

Lamarca Pérez, C., "Legislación penal antiterrorista: análisis crítico y propuestas», en Azpilcueta cuadernos de derecho, n. ${ }^{\circ}$ 20, 2008.

Llobet Anglí, M., Derecho Penal del terrorismo. Límites de su punición en un Estado democrático, La Ley, Madrid, 1. ${ }^{\text {a ed., }} 2010$.

Mayo Calderón, B., "Delitos contra el honor», en Derecho Penal. Parte Especial. Conforme a las leyes orgánicas 1 y 2/2015, de 30 de marzo, Boldova Pasamar (coord.), Comares, Granada, 1. ${ }^{\mathrm{a}}$ ed., 2016.

Mira Benavent, J., «El delito de enaltecimiento del terrorismo, el de humillación a las víctimas del terrorismo y la competencia de la Audiencia Nacional: ni delito, ni terrorismo, ni competencia de la Audiencia Nacional», en Terrorismo, Sistema Penal y Derechos Fundamentales, Alonso Rimo (dir.), Tirant lo Blanch, Valencia, 2018.

Miró Llinares, F., «Derecho penal y 140 caracteres. Hacia una exégesis restrictiva de los delitos de expresión", en Cometer delitos en $140 \mathrm{ca}$ racteres. El Derecho Penal ante el odio y la radicalización en Internet, Miró Llinares (dir.), Marcial Pons, Madrid, 1. ${ }^{\mathrm{a}}$ ed., 2017.

— «OFENDER COMO ACTO DE TERRORISMO. A propósito de los casos «César Strawberry» y "Cassandra Vera»», en Liber Amicorum. Estudios Jurídicos en Homenaje al Prof. Dr. Dr. h.c. Juan M. ${ }^{a}$ Terradillos Basoco, De la Cuesta Aguado (coord.), Tirant lo Blanch, Valencia, 1. ${ }^{\text {a }}$ ed., 2018.

Moral De La Rosa, J., Aspectos penales y criminológicos del terrorismo, Centro de Estudios Financieros, Madrid, 1. ${ }^{\text {a }}$ ed., 2005.

Muñoz Conde, F., Derecho Penal. Parte Especial, Tirant lo Blanch, Valencia, 21. ${ }^{\text {a }}$ ed., 2017.

MuÑoz CuEsta, J., «Interpretación del enaltecimiento de terrorismo conforme a la Directiva UE 2017/541, de 18 de marzo», en Revista Aranzadi Doctrinal, n. ${ }^{\circ} 8,2017$.

Paredes Castañón, J.M., «Terrorismo y principio de intervención mínima: una propuesta de despenalización», en Terrorismo, Sistema Penal y Derechos Fundamentales, Alonso Rimo (dir.), Tirant lo Blanch, Valencia, 1. ${ }^{a}$ ed., 2018.

Pastrana SÁnchez, M.A., «Interpretación judicial del derecho y terrorismo: Especial referencia al enaltecimiento», en Revista de Derecho

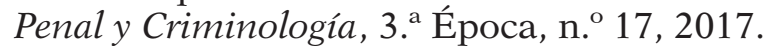

— «Apología del terrorismo y otros delitos afines: Evolución y tendencias en España y en el Perú», en Revista Derecho \& Sociedad, n. ${ }^{\circ}$ 52, 2019. 
Portilla Contreras, G., «El retorno de la censura y la caza de brujas anarquistas», en Cometer delitos en 140 caracteres. El Derecho Penal ante el odio y la radicalización en Internet, Miró Llinares (dir.), Marcial Pons, Madrid, 1. ${ }^{a}$ ed., 2017.

Ramos Vázquez, J.A., «Presente y futuro del delito de enaltecimiento y justificación del terrorismo», en Anuario da Facultade de Dereito da Universidade da Coruña, n. ${ }^{\circ}$ 12, 2008.

SÁez Valcárcel, R., «La libertad de expresión. Apariencia y realidad», en Boletín Límites a la libertad de expresión, Juezas y Jueces para la democracia, 2018.

Teruel Lozano, G.M., «Discursos extremos y libertad de expresión: un análisis jurisprudencial», en Revista de Estudios Jurídicos, ${ }^{\circ} 17$, 2017.

— «Internet, incitación al terrorismo y libertad de expresión en el marco europeo», en InDret, n. ${ }^{\circ}$ 3, 2018.

VIVES ANTÓN, T.S., «Sistema democrático y concepciones del bien jurídico: el problema de la apología del terrorismo», en Estudios penales y criminológicos, n. ${ }^{\circ} 25,2004$. 
